NBER WORKING PAPER SERIES

\title{
FEDERAL AID AND EQUALITY OF EDUCATIONAL OPPORTUNITY: EVIDENCE FROM THE INTRODUCTION OF TITLE I IN THE SOUTH
}

\author{
Elizabeth U. Cascio \\ Nora E. Gordon \\ Sarah J. Reber \\ Working Paper 17155 \\ http://www.nber.org/papers/w17155
}

\author{
NATIONAL BUREAU OF ECONOMIC RESEARCH \\ 1050 Massachusetts Avenue \\ Cambridge, MA 02138 \\ June 2011
}

This research was supported by grants from the National Science Foundation (Award Number 0519126) and the Spencer Foundation (Award Number 200600131). The authors also gratefully acknowledge support from the National Academy of Education/Spencer postdoctoral fellowship. We are grateful to Patricia Anderson, Sandra Black, Julie Cullen, Ethan Lewis, Robert Margo, Leah Platt Boustan, Douglas Staiger, and seminar participants at Stanford University, the University of Texas, the University of Wisconsin, and the NBER Economics of Education meeting for helpful comments and to Cyrus Kosar for excellent research assistance. We thank James Alt for providing the voting data, Douglas Miller and Jens Ludwig for providing identification of the 300 poorest counties, and Douglas Almond, Hilary Hoynes, and Diane Schanzenbach for providing REIS data. All errors are our own. The data presented, the statements made, and the views expressed are solely the responsibility of the authors, and do not necessarily reflect the views of the National Bureau of Economic Research.

NBER working papers are circulated for discussion and comment purposes. They have not been peerreviewed or been subject to the review by the NBER Board of Directors that accompanies official NBER publications.

(C) 2011 by Elizabeth U. Cascio, Nora E. Gordon, and Sarah J. Reber. All rights reserved. Short sections of text, not to exceed two paragraphs, may be quoted without explicit permission provided that full credit, including $\odot$ notice, is given to the source. 
Federal Aid and Equality of Educational Opportunity: Evidence from the Introduction of Title I in the South

Elizabeth U. Cascio, Nora E. Gordon, and Sarah J. Reber

NBER Working Paper No. 17155

June 2011

JEL No. H7,I2,J15

\section{ABSTRACT}

Title I of the 1965 Elementary and Secondary Education Act substantially increased federal aid for education, with the goal of expanding educational opportunity. Combining the timing of the program's introduction with variation in its intensity, we find that Title I increased school spending by 46 cents on the dollar in the average school district in the South and increased spending nearly dollar-for-dollar in Southern districts with little scope for local offset. Based on this differential fiscal response, we find that increases in school budgets from Title I decreased high school dropout rates for whites, but not blacks.

Elizabeth U. Cascio

Department of Economics

Dartmouth College

6106 Rockefeller Hall

Hanover, NH 03755

and NBER

elizabeth.u.cascio@dartmouth.edu

Nora E. Gordon

Georgetown Public Policy Institute

3520 Prospect Street NW, 4th Floor

Washington, DC 20007

and NBER

neg24@georgetown.edu

\author{
Sarah J. Reber \\ University of California, Los Angeles \\ Department of Public Policy \\ School of Public Affairs \\ 3250 Public Policy Building \\ Los Angeles, CA 90095 \\ and NBER \\ sreber@ucla.edu
}




\section{Introduction}

Intergovernmental grants are widely-used tools that may preserve the efficiency benefits associated with local provision of public goods while addressing equity concerns and crossjurisdictional externalities, as described in the theory of fiscal federalism (Musgrave, 1959; Oates, 1972, 1999). However, the intent of the granting government may be undermined if receiving jurisdictions crowd out intergovernmental grants by reducing their own fiscal effort or spend the grant ineffectively. The latter requirement may be nontrivial in policy contexts in which the production function for the outcome of ultimate interest is not fully understood.

Perhaps nowhere are these issues more salient in the U.S. than in education finance. Elementary and secondary education have long been provided by local school districts, but the importance of intergovernmental grants has increased over the past 50 years as both states and the federal government have contributed a larger share of total revenue. A large empirical literature has explored how school finance regimes at the state level have affected school spending (for example, Fisher and Papke, 2000; Hoxby, 2001). Per-pupil expenditure rose dramatically in recent decades, and a largely separate empirical literature examines how school spending during this era has affected student outcomes (see Hanushek, 1986, 1997 for reviews). Far fewer studies have examined both issues simultaneously or using variation from their policy origins. ${ }^{1}$

We do so in this paper, analyzing how Title I of the Elementary and Secondary Education Act of 1965 (ESEA) affected school spending and high school dropout rates in the years immediately following its introduction and the role of local institutional context in mediating

\footnotetext{
${ }^{1}$ Card and Payne (2002) use a national sample to examine how changes in the progressivity of school spending induced by state school finance reforms changed the distribution of SAT scores by income at the school district level. A related literature looks within individual states at effects of school finance reforms on local spending and outcomes: see Clark (2003) on Kentucky, Guryan (2001) on Massachusetts, and Papke (2005, 2008) and Roy (2011) on Michigan.
} 
these effects. ${ }^{2}$ Title I ESEA had a dramatic effect on federal education spending: During the fall of 1965, Congress doubled federal expenditure on education by appropriating almost $\$ 1$ billion to the new program, equivalent to $\$ 7$ billion in 2009 . The program was intended to assist school districts in providing programs for "educationally disadvantaged" children, but limited enforcement made the Title I grants highly fungible in practice, allowing them to take the form of general education aid (Martin and McClure, 1969).

We focus the present analysis on the impacts of Title I in the former Confederacy, which we refer to as the South. The South benefited disproportionately from the program and received grants that were relatively large, representing more than 20 percent of existing school spending in the average district. There was also wide variation across districts in the capacity to expropriate these large grants, making it possible for us to test whether the program affected educational attainment only where it increased spending on schools. The effects of Title I on the financing of schools and educational attainment are of particular historical interest for the South, where vast racial inequities in school resources and educational attainment developed after Reconstruction (Margo, 1990, Card and Krueger, 1992, 1996; Ashenfelter, Collins, and Yoon, 2006), and where education spending was quite low and educational outcomes poor by national standards even for whites. It was stark inequalities such as these that Title I sought to remedy.

We begin by evaluating the impact of Title I on school finance, combining the timing of the program's introduction with variation across school districts in its intensity, which was tied to child poverty in 1960 . Using newly-collected data and controlling for other local characteristics, we estimate that Title I grants increased school spending by 46 cents on the dollar

\footnotetext{
${ }^{2}$ Our analysis contributes to a growing literature on the effects of the introduction of other "War on Poverty" programs, including Medicare (Almond, Chay, and Greenstone, 2006; Finkelstein, 2007), Head Start (Ludwig and Miller, 2007), and the Food Stamp program (Hoynes and Schanzenbach, 2009; Almond, Hoynes, and Schanzenbach, 2011).
} 
in the average Southern district and crowded out local revenue, not state aid. These findings are robust to the inclusion of a wide range of controls, and the changes in the relationship between child poverty and fiscal outcomes are closely timed with the introduction of Title I, supporting a causal interpretation of the findings. At least in the South, the progressivity that characterizes school finance today began to emerge well before the well-studied state school finance equalization movement — albeit on a much smaller scale — in the mid-1960s as Title I went into effect. ${ }^{3}$

We next show that Southern institutions made crowd-out of Title I less than would have been predicted based on the income elasticity demand for education spending alone. In particular, Title I increased school spending significantly more — nearly dollar-for-dollar — in districts where the Title I grant was large relative to pre-program local revenue. These districts were arguably constrained by the large state grants and mandatory local contributions for education characteristic of the South and unable to reduce local effort as much as they would have liked, if at all. This finding demonstrates the importance of accounting for institutional environments in predicting and evaluating the effects of intergovernmental grants. For example, intergovernmental grants should only affect the ultimate outcome of interest in institutional settings where they increase spending. ${ }^{4}$

In this vein, we exploit the differential fiscal response by scope for local offset to identify the effects of Title I-induced spending on high school dropout rates of 18 and 19 year olds. The results suggest that "money mattered": each additional \$100 of Title I-induced annual current expenditure per pupil (2009 dollars) reduced white dropout rates by about 3 percentage points

\footnotetext{
${ }^{3}$ Margo (1990) and Goldin and Katz (2008) discuss the evolution of school finance earlier in the $20^{\text {th }}$ century. ${ }^{4}$ In a different policy context, Baicker and Staiger (2005) estimate that in states with institutional features that enabled expropriation, about half of federal Medicaid Disproportionate Share Hospital funding was crowded out by state governments, but the program was still a cost-effective means of reducing infant mortality. Van der Klaauw (2008), on the other hand, shows that "Title I schools" in New York City had no additional resources, so not surprisingly, there was no effect of Title I revenue on educational outcomes.
} 
over the 1960s. For blacks, by contrast, the estimates are statistically insignificant and wrongsigned, and, though consistent with moderate benefits of Title I-induced increases in school spending, precise enough to rule out effect sizes as large as those found for whites.

Overall, our findings suggest that Title I can account for over 20 percent of the growth in school spending and about one third of the decline in white high school dropout in the South over the 1960s. Local control over the use of Title I funds may have limited their scope to improve outcomes for blacks, possibly because there was little to prevent school districts from directing Title I funds to schools attended by whites, which remained largely separate from those attended by blacks in the South through $1968 .{ }^{5}$ Consistent with Reber's (2010) analysis for Louisiana, however, we also find that, separate from the effects of Title I, spending increased more and black high school dropout rates fell more in districts with higher black enrollment shares, where blacks experienced larger improvements in school quality over the 1960s as a result of desegregation. ${ }^{6}$

The remainder of the paper is structured as follows. Section II provides background on the Title I program. Section III describes a simple framework for analyzing intergovernmental grants, incorporating important institutional features of Southern school finance. Section IV analyzes the fiscal effects of the program, and Section V examines heterogeneity in these effects across districts. In Section VI, we assess the impact of Title I-induced expenditure on high school dropout rates by race. Section VII concludes.

\section{Title I of the Elementary and Secondary Education Act}

\footnotetext{
${ }^{5}$ In the 1968 Supreme Court ruling in Green v. New Kent County (391 U.S. 430), districts could no longer defend racially-identifiable schools by nominally offering "freedom of choice” plans. See Cascio et al. (2008) for more on the timing of Southern desegregation.

${ }^{6}$ This result is most analagous to Reber (2010), but a larger literature suggests that both desegregation and predesegregation narrowing of black-white school quality gaps benefited blacks on a variety of outcomes (Card and Krueger, 1992; Ashenfelter, Collins, and Yoon, 2006; Guryan, 2004; Johnson, 2011).
} 
Title I funds were first allocated to school districts in the fall of $1965 .^{7}$ In keeping with its policy origins as part of President Johnson’s “War on Poverty,” the Title I formula relied heavily on child poverty counts in determining allocations to school districts. At the program's start, districts received a state-specific payment (the "state factor") per eligible child. Eligibility counts were largely determined by the number of 5 to 17 year olds with family income below $\$ 2000$ in the 1960 Census. The state factor was initially equal to 50 percent of statewide mean current expenditures, net of federal revenue, per pupil, lagged two years. Starting in fall 1967, however, variation in the state factor remained only for those states that spent above the national average, and the allocation per eligible child in all other states (including all of the states in our sample except Florida) was leveled up to the national average. In the South, this meant that child poverty was essentially the sole determinant of Title I grants after 1967 (U.S. DHEW, 1969).

The influx of federal funds to the South from Title I was unprecedented. Figure I shows that the federal government was a negligible source of revenue for the average Southern school district prior to passage of ESEA in 1965, with the limited federal funds largely disbursed through Aid to Federally Impacted Areas and the National Defense Education Act. As shown in the second column of Table I, in 1964, federal revenue in the average Southern district in our sample only amounted to $\$ 65$ per pupil (in real 2009 dollars) - about 3.5 percent of per-pupil current expenditures. By the end of the decade, per-pupil federal revenue had increased dramatically, by $\$ 420$ (column (5)), and had come to represent 17 percent of per-pupil current expenditure in the average Southern district.

There was little about Title I's enforcement that ensured the program would translate into increased compensatory services for poor children. In the early years of ESEA, regulations specified only that Title I funds should "supplement and not supplant” local funds; while the

\footnotetext{
${ }^{7}$ See Bailey and Mosher (1968) for a comprehensive description of Title I administration in its early years.
} 
Department of Health, Education, and Welfare conducted district-level audits, it did not require districts to return funds that were misused. The program was criticized as a fungible supplement to general revenue as opposed to a targeted and defined compensatory intervention, most influentially in a 1969 report by the NAACP Legal Defense Fund (Martin and McClure, 1969). Such criticisms sparked a series of regulations and legislative changes still embedded in the system today, which is often criticized as being overly restrictive and compliance-focused. But even today's complex regulatory framework and serious enforcement efforts cannot prevent districts from appropriating Title I funds, either for private consumption or for other educational purposes. $^{8}$

Thus, Title I essentially took the form of a restricted block grant for education to a local school district during the period of study. Accordingly, we consider current expenditure on education to be the "targeted good" of the program. To the extent that Title I did raise current expenditure, it could easily have been focused on instructional areas or groups of students other than those nominally designated as its beneficiaries. This is particularly interesting for the South, where prior to 1968, most districts operated racially identifiable schools and may therefore have had some ability to direct additional funding disproportionately to whites.

\section{A Framework for Understanding Fiscal Responses to Title I Grants in the South}

How much Title I translated into higher current expenditure on education depends on how much lower levels of government offset Title I revenue by reducing their own contributions to education spending. Both local and state governments could have responded to the influx of federal funding, so we consider each in turn.

III.A. Local District Responses to Title I Grants

\footnotetext{
${ }^{8}$ For example, see Gordon (2004) on how maintenance of effort requirements do not prevent crowd out of local revenue and Roza (2010) on how comparability requirements do not ensure that Title I funds are concentrated in the poorest schools within districts. Cohen and Moffitt (2009) discuss the range of implementation challenges.
} 
We begin with a standard neoclassical model where a local school district (presumably the median voter) chooses its level of consumption of educational services and all other goods, including private consumption. ${ }^{9}$ Districts can reallocate consumption by altering the tax rate. We incorporate into the standard model two important institutional features of Southern state school finance systems during the 1960s. First, state aid was significant, accounting for well over half of the typical school district's total revenue (Figure I and Table I), compared to about 30 percent outside the South. The vast majority of this aid (typically upwards of 80 percent) was distributed through minimum foundation programs (MFPs), which took the form of a restricted block grant from the school district perspective. ${ }^{10}$ Second, school districts could not reduce local revenue below some minimum, since state constitutions or MFPs in all states in our sample imposed a minimum required contribution to education on local school districts. Both of these factors - the magnitude of state education aid and minimum required local contributions to education - would have limited the scope for Southern school districts to crowd out Title I grants.

Figure II illustrates the choice problem for a Southern district before and after Title I funds were distributed. The innermost budget constraint (BC1) shows the pure local finance case where prices are normalized to one and the district could allocate total income $I$ freely between educational services $(E)$ and all other goods $(C)$, including private consumption. BC2 accounts for state aid and the minimum local contribution with a parallel outward shift of the budget

\footnotetext{
${ }^{9}$ The median voter in the South would have been white and Southern school boards would have been controlled by whites throughout this period in most or all of the districts in our sample (see U.S. Commission on Civil Rights, 1968). Schools were also largely segregated by race until at least 1969, raising the possibility that funding was not allocated equally across schools within districts, particularly by race. This is important in interpreting the effects of Title I on educational outcomes by race, and we return to this issue below. For simplicity, we do not incorporate race into the model explicitly.

${ }^{10}$ Not all of the programs were referred to as MFPs, but those that were not had the same general structure. MFPs contrast to many modern state school finance regimes which employ various forms of matching and therefore change relative prices. Grants under state MFPs were not pure block grants in the sense that some district choices (e.g. the distribution of teacher experience) could affect the amount of the grant. We abstract from these issues here, since they likely had small effects and in any case are unrelated to the Title I grant.
} 
constraint, and thus represents the scenario before Title I. A district had to spend at least as much as the state grant plus the minimum local contribution on education, so the maximum spending on $C$ was $I$ less the minimum local contribution; that is, the dashed part of the budget constraint was inaccessible. The introduction of Title I caused a further parallel shift in the budget constraint to BC3 (the figure depicts a large Title I grant for illustrative purposes). After Title I, the district had to spend at least as much as previously required plus the Title I grant on education, so the dashed part of the new budget constraint was inaccessible.

The Title I grant produced only an income effect. School districts would have liked to increase their spending on both $E$ and $C$ according to the relevant income elasticities, in which case the increase in $E$ would have been less than the size of the grant. ${ }^{11}$ A district would have increased $E$ more than this only if its optimal bundle was on the inaccessible (dashed) portion of the budget constraint, in which case, it would have been forced to the corner (point $\mathrm{Z}$ ). The presence of state aid and minimum local contributions in the South increased the chances that some districts were constrained and increased $E$ more than the income elasticity would imply, and this effect would have been larger when either the state grant or the minimum local contribution was larger. The figure illustrates an extreme case where spending increases one-forone with Title I: the district at the corner before the implementation of Title I (point X), would have liked to move to point $\mathrm{Y}$ on BC3, given the income elasticity of education demand, but was restricted to choose the new corner, $\mathrm{Z}$.

Much of the literature on intergovernmental grants finds that grants increase spending on the targeted good more than would be implied by the income elasticity of demand. This is referred to as a "flypaper effect," since the grant disproportionately "sticks where it hits.” In

\footnotetext{
${ }^{11}$ In the language of Bradford and Oates (1971), this assumes that a sole grant to the collectivity of individuals in the school district has identical impact as a set of individual-level grants summing to the same amount.
} 
some cases, these effects have been demonstrated to be statistical artifacts generated by omitted variables, such as local preferences or other characteristics determining the magnitude of the grant (Knight, 2002; Gordon, 2004). In others, the effect is attributed either to some disconnect between the true preferences of voters and spending chosen by governments (e.g., due to "bureaucratic capture,” when a constituency for a specific program develops and is able to prevent voters from reducing spending), or to behavioral tendencies that lead voters to view spending out of local taxes differently than spending out of intergovernmental grants (see Hines and Thaler (1995) for a review). The framework above suggests that if institutional constraints limit the scope for offset, grants should generate larger increases in spending on the targeted good than predicted by the income elasticity even assuming the rational choices of the median voter are not suppressed or altered by bureaucratic actions. ${ }^{12}$ We assess the importance of such constraints in Section $\mathrm{V}$ by examining whether spending on education increased more as a result of Title I among districts that were more likely to face constraints on local offset.

\section{III.B. State Responses to Title I Grants}

The objective function of state governments is more complicated than that of a school district due to its additional policy functions beyond education, and we do not explicitly model it here. We can say, however, how a state government wishing to replicate the pre-Title I distribution of total aid (state plus federal) across districts after Title I was implemented would have responded. First, the state would have reduced the average grant to account for the fact that on average districts were receiving more federal aid. Second, aid to poorer districts, which received larger Title I grants, would have been reduced relative to aid to richer districts.

\footnotetext{
${ }^{12}$ Relatedly, Brooks and Phillips (2010) find that federal funds stimulate higher levels of expenditure in local jurisdictions subject to tax and expenditure limits (TELs); they posit that TELs constrain such jurisdictions to suboptimally low levels of spending prior to receipt of the intergovernmental grant, explaining the differential responsiveness.
} 
Our empirical strategy allows for identification only of the latter type of response whether states changed how progressively they distributed funds. Allocation of funding under the MFPs typical of the South during this period was formula-based, and the poverty rate did not directly enter the funding formula in any state in our sample; thus, it might appear difficult for states to significantly change the progressivity of funding without undertaking a major reform. On the other hand, the formulas were complex, with inputs that may have been correlated with poverty rates, and in the early 1960s state aid was indeed moderately progressive. ${ }^{13}$ Ultimately, it is an empirical question to what extent states were able and willing to change the progressivity of their funding formulas in response to Title I.

\section{Fiscal Reponses to Title I}

\section{IV.A. Empirical Strategy}

Recall that Title I funds were initially allocated by a simple linear rule: districts received a constant amount of federal funds for each Title I eligible student. Title I eligibility, in turn, was determined primarily based on the number of 5 to 17 year-olds with family income below $\$ 2,000$ in the 1960 Census. A transparent approach to estimating the fiscal impacts of Title I’s introduction is therefore to explore how the gradient of a fiscal outcome in "initial" district child poverty, defined using these eligibility counts, changed over the 1960s. The identifying assumption is that, if the Title I program had not been introduced, there would not have been a break in this gradient as of 1965 .

More formally, we begin with the estimating equation

$$
y_{d s t}=\delta_{d}+\gamma_{s t}+\theta_{t} \text { child_poverty }{ }_{d}+x_{d}^{\prime} \beta_{t}+\varepsilon_{d s t} .
$$

\footnotetext{
${ }^{13}$ Reber (2011) shows that the state of Louisiana was able to redistribute state aid substantially in response to desegregation (directing additional funding to districts with higher black enrollment shares) by subtly manipulating the parameters of the existing MFP.
} 
The dependent variable $y_{d s t}$ represents one of four fiscal outcomes, each measured in per-pupil terms and in real 2009 dollars - current expenditure and revenue by source (federal, state, and local) - in district $d$ in state $s$ in the fall of year t. child_poverty ${ }_{d}$ is the initial child poverty rate in district $d$, which we define as the ratio of the district's Title I eligibility count in 1965, based largely on the 1960 Census, to its 1960 enrollment. This measure captures the effective poverty rate for distribution of Title I funds had district enrollment not diverged from its 1960 level. $\delta_{d}$ is a district intercept, which accounts for unobserved differences across districts in school finance that are fixed over time; $\gamma_{s t}$ is a state-by-year specific intercept, which accounts for any yearspecific shocks to fiscal outcomes common to all districts in a state; and $x_{d}$ is a vector including other district characteristics. We estimate model (1) using annual school finance data from 1961 to 1969 collected from print publications from the nine Southern states where such data are available. ${ }^{14}$ All the data and sources are described in detail in Appendix A.

The coefficients of interest in model (1) are the $\theta_{t}$ 's, which characterize the time path in fiscal outcomes in initially richer versus initially poorer districts. If Title I raised school expenditures, we would expect to see an increase in the poverty gradient in per-pupil current expenditure — i.e., in the progressivity of spending per pupil — as of 1965. Note, however, that model (1) does not force the effects of Title I to be isolated to the period in which the program was in place or to be the same across all years after the program was implemented. Rather, model (1) is a flexible specification that allows us to explore not only whether the poverty gradient in school spending changed in 1965, but also whether the poverty gradient in spending

\footnotetext{
${ }^{14}$ These states are Alabama, Florida, Georgia, Louisiana, Mississippi, North Carolina, South Carolina, Tennessee, and Virginia. Most districts in these states are included in our estimation sample, which is described in Appendix A. We are not able to incorporate districts from Arkansas and Texas - the two other former Confederate states - due to limitations in available data.
} 
was already changing in the early 1960s. If Title I affected fiscal outcomes, pre-program changes in the poverty gradient should be small relative to post-program changes.

Model (1) allows for time-varying effects of a vector of other initial district characteristics. We are most concerned about controlling for district characteristics correlated with initial poverty and associated with changes in demand for school spending in the mid1960s. In this vein, the most important threat to identification stems from school desegregation. The likelihood that the average Southern district had any blacks in school with whites increased sharply between 1964 and 1966, in part because the Civil Rights Act (CRA) tied receipt of Title I funds to desegregation (Cascio, et al., 2010). The desegregation required was limited, and most likely did not change the (white) median voter’s demand for education funding, as racially separate schools were maintained over this period. But between 1968 and 1970, the desegregation required for CRA compliance and by federal courts quickly intensified, and racially identifiable schools in the South were largely dismantled (Cascio, et al., 2008). The elimination of separate black and white schools required a major reorganization of schools and may have changed demand for school spending on public education. Demand may have fallen particularly if whites left the public schools in large numbers ${ }^{15}$ - or increased as whites attempted to increase the spending in newly integrated schools to the level to which they were accustomed in their schools before desegregation. Reber (2011) finds evidence in favor of the latter in a study of Louisiana over this period.

Following Reber (2011), our primary control for the effects of desegregation on district finances is the district's initial (1960) black enrollment share. Despite a half-century of progress towards convergence, black-white school resource gaps remained larger in districts with higher

\footnotetext{
${ }^{15}$ See Clotfelter (1976), Reber (2011), and Baum-Snow and Lutz (2011) for evidence on white flight to private schools as a result of desegregation in the South.
} 
black enrollment shares at mid-century (Margo, 1990; Card and Krueger, 1992; Reber 2011). As a result, maintaining whites' school quality required larger increases in funding in blacker districts. Reber (2011) shows that such funding increases began in Louisiana as early as 1966. Because black enrollment share is positively correlated with child_poverty ${ }_{d}$, omitting it would affect estimates of the $\theta_{t}$ 's in model (1). However, once (linear) black enrollment share is included in the model, controlling for it more flexibly or adding other controls for the intensity of desegregation in the South during the 1960s does little to affect our estimates.

In addition to 1960 black enrollment share, our main specification also controls for the share of the vote cast for Strom Thurmond in the 1948 presidential election, a proxy for segregationist preferences, and for 1960 enrollment, a measure of district size, both of which predict the pace of desegregation in the South over the period of study (Cascio, et al., 2008). In robustness checks, we also include controls for the share of whites enrolled in private schools in spring 1970, the extent of school desegregation, and an indicator for whether the district was desegregating under court order in fall 1970, each of which might be related to the intensity of desegregation. Summary statistics for the independent variables are presented in Table II. In the average district, the 1960 share of children in poverty and the black enrollment share were both about one third, and average enrollment was just under 7,000 students. The average district was in a county where 34 percent of the electorate voted for Thurmond in 1948.

We also explore alternative hypotheses for changes in the poverty gradient in school finances starting in 1965, including increases in black political power following the Voting Rights Act (VRA) of 1965 and funding increases under Head Start, another program for poor children implemented in the mid-1960s that sometimes channeled funds through school districts. As a proxy for the former, we control for the black voter registration rate in the early 1960s, an 
indicator for how suppressed the vote was before VRA (Alt, 1995).${ }^{16}$ As a proxy for the latter, we include an indicator for whether the district was in one of the 300 poorest counties, which received special grant-writing assistance for Head Start in the 1960s (Ludwig and Miller, 2007). Once the black share of enrollment is included in the regression, the coefficients of interest are little affected by the inclusion of a wide range of controls.

\section{IV.B. Graphical Evidence}

We first present the estimates of the flexible model graphically. Figure III plots yearspecific coefficients on child_poverty ${ }_{d}$ from model (1) estimated for the key fiscal variables. In addition to district and state-by-year fixed effects, our baseline specification includes the yearspecific effects of characteristics that were measured before the implementation of Title I and are available for the full sample: the 1960 black enrollment share, 1960 district enrollment (natural log), 1948 Thurmond vote share (quintile indicators), and whether the district is in one of the 300 poorest counties. The standard errors are clustered on county to account for possible correlation in the error terms over time within county. ${ }^{17}$ The point estimates are represented by dots; the x's denote $95 \%$ confidence intervals. ${ }^{18}$

Panel A shows that the poverty gradient in per-pupil federal revenue was little changed in the early 1960s but increased in 1965, the first year in which Title I funds were distributed. The estimates for per-pupil current expenditure, shown in Panel B, follow the same pattern: the progressivity of school spending trended little in the early 1960s but increased in 1965, suggesting that Title I played a causal role in tipping the balance of school expenditure from

\footnotetext{
${ }^{16}$ The exact year black voter registration is measured differs across states subject to data availability.

${ }^{17}$ We cluster standard errors on county because we use county-level information to predict district-level poverty rates (see Appendix A), and because Thurmond vote share is measured at the county level.

${ }^{18}$ Only the trend in the coefficients on child_poverty ${ }_{d}$, and not the level, is identified in model (1); we therefore rescale the graph so that the 1961 coefficient is equal to the coefficient on child_poverty ${ }_{d}$ in 1961 from a crosssectional regression including all of the same controls except district fixed effects.
} 
richer to poorer districts in the South. However, the increase in the poverty gradient in per-pupil school expenditure was less than the increase in the poverty gradient in per-pupil federal funding: Title I funds did not translate one-for-one to higher spending on education. Panel C shows that the distribution of state aid was somewhat progressive throughout the 1960s, but the progressivity did not change after 1965, suggesting that state governments did not offset Title I grants. ${ }^{19}$ On the other hand, Panel D shows that the poverty gradient in local effort became more negative after 1965, suggestive of local effort declining in response to Title I.

In sum, Figure III shows that, relative to richer districts, poorer districts experienced larger increases in federal revenue and current expenditure per pupil and larger declines in local revenue per pupil over the 1960s. These changes were closely timed with the introduction of Title I in 1965, suggesting that the introduction of Title I increased spending on education, but less than one for one, as local districts responded by reducing their own effort.

\section{IV.C. Change Regressions}

To facilitate tests of statistical significance for changes in the poverty gradient associated with Title I, to assess the sensitivity of the results to further controls, and to present results with more interpretable scaling, we estimate regressions for changes in the school finance variables around the time of Title I implementation. Differencing (1) across any two years, we arrive at:

$$
\Delta y_{d s}=\tilde{\gamma}_{s}+\tilde{\theta} \text { child_poverty }{ }_{d}+x_{d}^{\prime} \widetilde{\beta}+\Delta \varepsilon_{d s} .
$$

\footnotetext{
${ }^{19}$ Our research design does not allow us to identify the effects of Title I on average state aid, but what evidence there is suggests that state offset on this margin was likely minimal. First, as shown in Figure I, there is a strong upward trend in state revenue over the late 1960s, although of course this trend may have been even steeper in the absence of Title I. Second, if states that received more Title I funding responded by reducing average state funding, we might expect to see a negative relationship between the state-level poverty rate and average state funding. In fact, the state fixed effects in the model for changes in per-pupil state revenues - a measure of the average change in the state - are uncorrelated with the state poverty rate. Ultimately, we do not have a credible source of variation with which to identify the average state response, so we view this evidence as suggestive.
} 
The state fixed effects, $\tilde{\gamma}_{s}$, account for trends in fiscal outcomes common to districts in the same state, and the coefficients on the controls, $\tilde{\beta}$, give changes over time in the gradients of fiscal outcomes in a district's initial characteristics. $\tilde{\theta}$ is the coefficient of interest, indicating the extent to which the gradient of fiscal outcomes in initial district child poverty changed over time. The district fixed effect in (1) is absorbed in taking the first difference.

We estimate model (2) for long changes around the introduction of Title I - one postprogram (1964 to 1969) and one pre-program (1961 to 1964). The post-program period is sufficiently long to allow time for districts and states to respond to the new program, such that the results might reflect a new equilibrium. ${ }^{20}$ In practice, the results are not sensitive to the choice of end year. Summary statistics for the dependent variables are presented in the last two columns of Table I.

The first column of Table III presents estimates of model (2) for the post-program change, using the same controls included in the regressions plotted in Figure III; the coefficient on child_poverty ${ }_{d}$ is thus simply the difference in coefficients for 1964 and 1969 shown in the figure. In the model for the change in per-pupil federal funding, in Panel A, the coefficient on the 1960 child poverty rate $-\$ 929$ (with a standard error of $\$ 74$ ) - is, as expected, quite close to the average state factor in the Title I grant formula as of 1969 - \$954, shown in Table II. ${ }^{21}$ Per-pupil current expenditure increased by $\$ 425$ more between 1964 and 1969 in a district with only poor

\footnotetext{
${ }^{20}$ Gordon (2004) shows how local crowd-out of Title I in the 1990s phased in over a three-year period following changes in grant amounts. An additional consideration is that 1969 was after the Nixon Administration stopped enforcement of the federal-funds-withholding provisions of CRA (Orfield, 2000), breaking the explicit link between desegregation and Title I receipt. We do not consider any later years because the federal government began providing aid to desegregating districts in a way that appears correlated with child poverty in 1970.

${ }^{21}$ If all districts received their formula amounts under the Title I program, we would expect the change in the poverty gradient from 1964 to any year from 1965 to 1969 to be roughly equal to the average grant received for each eligible child (the "state factor") in that year. The coefficients on child_poverty in 1965 and 1966 are less than this since some Southern districts did not receive Title I funds due to non-compliance with CRA. Data on the state factor in the Title I formula was drawn from county-level data published in a series of Congressional reports. See Appendix A.
} 
children compared to a district with no poor children (Panel B). Rescaling by the corresponding change in per-pupil federal revenue, these estimates imply that each additional dollar increase in per-pupil federal revenue received over 1964 to 1969 generated a 46 cent increase in per-pupil current expenditure. $^{22}$

We formalize this rescaling of the estimates into more intuitive "dollar-for-dollar" terms in column (2), using child_poverty as an instrument for the change in federal revenue in a twostage least squares (TSLS) regression. Focusing on these estimates, there is little evidence of crowd-out by state governments (Panel C), but local revenue declined by about 33 cents for each additional dollar of federal revenue (Panel D). Thus, our estimates leave a statistically significant 26 cents of federal revenue unaccounted for (Panel E): each dollar of additional federal revenue increased current expenditure by 46 cents, but there was only 28 cents of total crowd out (33 cents local less five cents state). This differential could represent an increase in spending on capital and debt service, which are included in total, but not current, expenditure. The data we have on total expenditure are incomplete and less reliable than the data for current expenditure, ${ }^{23}$ but when we estimate the model for the subset of states for which we have data, the results are similar to those for current expenditure but less precise, suggesting Title I did not increase spending on capital and debt service. Technically, this implies that districts used some

\footnotetext{
${ }^{22}$ Feldstein (1978) provides cross-sectional flypaper estimates of Title I from 1970, and finds spending increases by 80 cents per dollar of grant. Gordon (2004) exploits formula-based changes in funding in the early 1990s and estimates essentially full local crowd out and no impact on current spending, but with large confidence intervals (Gordon, 2004). Our findings here thus fall between the extremely wide range of limited estimates in the literature. ${ }^{23}$ For two states (NC and GA), we were not able to obtain data on total expenditure. Reporting of total expenditure is not as consistent across states as current expenditure and revenue by source, and because total expenditure includes capital expenditure, it exhibits much more year-to-year variation. In addition, while in theory, total revenue should be similar to total expenditure, at least on average and over longer time periods, in practice, this is not always the case. Capital outlays (part of total expenditure) can generate substantial departures of total expenditure from total revenue in a given year. Finally, at least some states do not count proceeds from bond issues as "revenue," while the capital improvements financed by bond issues are included in total expenditure; thus, revenue can be persistently lower than expenditure.
} 
of the new federal revenue to reduce debt or build up reserves, which would imply lower taxes in the future and could therefore be considered another form of local crowd-out.

Estimates of (2) for pre-program changes, given in column (3), largely confirm the visual impression in Figure III that changes in the poverty gradient in the years leading up to Title I implementation were small relative to the effects observed after. Per-pupil current expenditure declined slightly more over the early 1960s in poorer districts, but the coefficient is not statistically significant. There is some evidence of a small disproportionate shift from local to state funding for poorer districts, as the coefficient in the state revenue regression is positive and the coefficient in the local revenue regression is negative, significant at the 5 and 10 percent level, respectively. As can be seen in Figure III, these changes were small relative to changes in fiscal outcomes after 1964, and when we include separate controls for pre-program changes in per-pupil state and local revenue, the results are unchanged (results reported below in column (8) of Table IV). Still, the estimates in column (2) of Table III assume that there would have been no trend in the poverty gradient between 1964 and 1969 in the absence of the program. If, similar to the approach taken in Finkelstein (2007), we instead take the trend from 1961 to 1964 as the counterfactual, our substantive conclusions that Title I increased school expenditure and reduced local effort are unchanged, though the estimates from this exercise imply slightly larger expenditure responses and slightly less local offset (results available on request).

While our estimates do not account for every cent of Title I revenue, they have confidence intervals that allow us to make economically meaningful conclusions about the program's fiscal impacts. We can rule out substantial reallocation of state funds, and the confidence interval for local revenue suggests local districts engaged in economically meaningful offset. The estimate for current expenditure (the targeted good) is significantly 
different from both one and zero, and also significantly larger than existing estimates of the income elasticity of education demand would imply - 12 to 19 cents per dollar in the average district, according to our back-of-the-envelope estimate. ${ }^{24}$ This suggests that at least some districts were either constrained to increase spending on education more than they would have liked given income and prices, or that grants disproportionately "stuck" for other reasons. We explore this in more detail in the next section.

\section{IV.D. Robustness}

As described above, the primary threat to identification in our empirical strategy comes from desegregation-related changes to school finance. Our main control for the effects of desegregation is black enrollment share. Before exploring how our estimates change with more extensive controls, it is useful to confirm that the relationship between black enrollment share and changes in fiscal outcomes align with expectations. To this end, we present coefficients on black share from estimates of model (2) in Table III. Black enrollment share is positively related to changes in per-pupil current expenditure over 1964 to 1969, consistent with the prediction that demand for funding increased more in blacker districts due to desegregation and with the results for Louisiana reported in Reber (2011).

Table IV shows that the coefficients of interest are remarkably insensitive to the inclusion of more controls or more flexible functional forms. Column (1) repeats the TSLS estimates in column (2) of Table III. In column (2), the indicator for being in one of the poorest 300 counties and the Thurmond vote share controls are removed; the estimates are little changed. Columns (3) and (4) show the estimates under alternative specifications of 1960 enrollment and black

\footnotetext{
${ }^{24}$ Put differently, the income elasticity would have to be about 1.5 to explain our estimates of the Title I-induced increase in education spending. Fisher and Papke (2001) review the literature and cite income elasticity of demand for public education spending estimates that do not approach this, ranging from 0.40 to 0.65 . See Appendix B for details on this calculation.
} 
share in a model that otherwise includes only state fixed effects: in column (3) black share and enrollment are both interacted with state fixed effects, and column (4) is the same as (1) but includes indicators for deciles of black enrollment share in lieu of the linear term. The results are not sensitive to the functional form of black share and enrollment, so we use the baseline linear specification.

The next columns in Table IV add several sets of controls to further account for the effects of desegregation and other coincident policy changes. In column (5), we include several direct measures of desegregation by 1970 -the dissimilarity index and an indicator for whether the district was desegregating under court supervision at that time ${ }^{25}$-as well as the share of the white population enrolled in private schools in spring $1970 .{ }^{26}$ Column (6) adds a control for the 1960 black voter registration rate to examine the hypothesis that increases in black political participation after VRA changed the demand for school spending. ${ }^{27}$ Estimates from a specification that controls for changes in federal spending on other programs at the county level — including spending on Head Start, public assistance, retirement programs, and health programs - are reported in column (7). Finally, we include controls for pre-program changes in per-pupil local and state revenue (separately) in column (8). The estimates are quite similar to the baseline estimates regardless of which additional controls are included.

\section{Heterogeneous Fiscal Responses to Title I Grants}

For the average Southern school district, each dollar of federal revenue distributed through Title I in the 1960s increased current expenditure by about 46 cents - more than what

\footnotetext{
${ }^{25}$ Controlling for variables measured after the introduction of Title I raises the possibility of reverse causation, as changes in financing could theoretically influence desegregation, so we do not include these variables in the main specification. In this historical context we do not perceive this is a likely or influential mechanism, however. Prior to the passage of ESEA, there was essentially no variation in these desegregation variables.

${ }^{26}$ Ideally, we would use the change in private enrollment, but these data are not available for 1960 . Private enrollment rates were historically quite low in the South but increased somewhat during the period of desegregation. ${ }^{27}$ Voting-related changes in blacks' political power are likely also related to the black share of the population, which is highly correlated with the black share of enrollment already included in the regression.
} 
reasonable estimates of the income elasticity of demand for education would imply. What forces underlie this finding? One possibility, highlighted in Section III, is that current expenditure increased more - and local revenue declined less - in districts where the median voter wanted to consume on the restricted portion of the budget constraint but was forced to the corner. ${ }^{28}$ We do not have the data to identify the corner precisely, but we can test whether districts that were more likely to have been constrained, given their prior local effort and Title I grant, increased current expenditure more and reduced local funding less. In addition to furthering our understanding of how fiscal constraints might shape responses to intergovernmental grants, this analysis of heterogeneity provides a valuable internal validity check on our earlier estimates and the foundations of our strategy for estimating the effects of Title I on student outcomes.

To understand our measure of "scope for local offset," it is useful to return to Figure II. A larger Title I grant would have shifted out BC3 by more, increasing the probability that a district preferred to consume on its inaccessible portion, and districts with low initial local revenue would have had less scope to offset the Title I grant by lowering local revenue, all else equal. Thus, the districts most likely to have been constrained were those that received large Title I grants relative to the local revenue they would have raised in the absence of the program in the same year. We cannot observe this counterfactual local revenue, but it is likely highly correlated with local revenue prior to Title I. We therefore use the ratio of the district's 1969 Title I grant to 1964 (pre-program) local revenue as a proxy for the scope for local offset. This proxy orders districts by their scope for offset but has no natural scale. We split the sample at the $75^{\text {th }}$ percentile and consider the top quartile to encompass "low scope for offset” districts; our findings are qualitatively similar but the differences less dramatic if we split the sample into two

\footnotetext{
${ }^{28}$ Differences in income elasticities would also generate differences in fiscal responses. We are not aware of credible estimates of how the income elasticity of demand for education varies across districts.
} 
equal-sized groups (available on request). Because low scope for offset districts received larger Title I grants, these districts were poorer on average, but there is significant variation in the poverty rate within each category. ${ }^{29}$

Table V, Panel A shows how fiscal responses to Title I varied by scope for offset. Instead of estimating separate TSLS models for each subsample, we estimate a pooled regression so as to test whether fiscal responses to Title I were significantly different across the two groups. We instrument for the change in per-pupil federal revenue and its interaction with the low scope for offset indicator with the child poverty rate and its interaction with low scope for offset and include interactions between low scope for offset and most controls in the baseline specification (black share in enrollment, district enrollment, and state dummies). The estimates from a fullyinteracted model are very similar but slightly less precise, and the findings are similar when we include the different sets of controls in Table IV (results available on request).

The results suggest that current expenditure increased significantly more between 1964 and 1969 in districts with low scope for offset - 91 cents for each dollar of federal revenue, compared to 23 cents for districts without low scope for offset (column (1)). There are no significant differences across these two groups of districts in state revenue responses (column (2)), though the standard errors do not allow us to rule out economically interesting effects. The results for local revenue (column (3)) suggest that the quarter of districts with low scope for offset did not reduce local revenue in response to federal funding, while the remaining districts reduced local revenue by 58 cents for each dollar of federal revenue. The coefficients actually suggest (marginally significant) crowding in among low scope for offset districts. As shown in Appendix Figure I, the poverty gradients of per-pupil current expenditure and per-pupil local

\footnotetext{
${ }^{29}$ The standard deviation of the child poverty rate is 0.17 in the full sample (Table II). Significant variance remains within each of the two scope for offset subsamples, with a standard deviation of 0.14 for each.
} 
revenue for the two "scope for offset" groups diverged quickly after ESEA was passed, but trended similarly - and changed little - in the early 1960s.

In light of race relations in the South, we also examine heterogeneity by racial composition. Variation in fiscal effects of Title I by black enrollment share may map to other sources of a "flypaper effect," such as the median (white) voter being more willing to spend on blacks out of federal revenue than out of local taxes. Panel B shows estimates analogous to those in Panel A, but stratifying districts by black share. The results suggest that current expenditure increased by about twice as much per dollar of federal revenue in high black enrollment share districts, due to less local offset. ${ }^{30}$ While this is consistent with whites being more willing to spend on blacks out of federal revenue, racial composition is also correlated with scope for offset, since high black share districts received larger Title I grants and had lower initial local revenue. Panel C presents estimates of the specification with both interactions included to determine whether racial composition or scope for offset is responsible for the differential response. For current expenditure and local revenue, the coefficient on the interaction between low scope for offset and the change in federal funding is similar to that in Panel A and maintains significance at the one percent level, while the coefficient on the interaction between high black share and the change in federal funding becomes statistically insignificant and is close to zero.

The fact that the scope for offset interaction coefficients are relatively stable across specifications, combined with the theoretical prediction that scope for offset should matter for fiscal responses, suggests that institutional factors were an important mediator of fiscal responses to Title I. However, we cannot rule out that districts we characterize as "low scope for offset" were not legally constrained to the corner solution, but rather were disproportionately subject to

\footnotetext{
${ }^{30}$ Again, we divided the sample into quartiles and define districts in the top quartile (corresponding to at least approximately 50 percent black enrollment) as "high black enrollment share.” Results are similar but less stark if we define high black enrollment share as above the median.
} 
bureaucratic capture or mental accounting. The point estimates can be squared with the assumption of no other such sources of flypaper effects only if a non-trivial share of districts faced significant institutional constraints on reducing local revenue. ${ }^{31}$ Unfortunately, we lack the data (e.g., on the proxies for bureaucratic capture used in the literature ${ }^{32}$ ) to explore other reasons why the effects of Title I on education spending are larger than the income elasticity of education demand alone would generate. ${ }^{33}$

\section{Title I and Educational Attainment}

The results thus far suggest that Title I raised school spending in the South, and more so in districts where the grants were large relative to expected local revenue, where the ability to offset Title I funds was likely constrained. Did these increases in school spending improve student outcomes? Recall that there was limited enforcement of targeting during this era, so Title I-induced increases in school expenditure could easily have benefitted children who were not “educationally disadvantaged.” We therefore examine how Title I affected all students and view our analysis as being more closely related to the literature on the effects of school spending

\footnotetext{
${ }^{31}$ Our measure of scope for offset does not have a natural scale, but the point estimates indicate one-for-one increases in spending with federal revenue and no offset for low scope for offset districts, implying that a quarter of districts would have consumed at the corner both with and without the Title I grant in the context of the neoclassical model. Among the remaining districts, the increase in spending (21 cents per dollar) is consistent with an income elasticity of demand for education spending of about 0.7 . In some states, we have more detailed breakdowns of local revenue, and based on the limited data we have, there do not appear to have been districts that were raising only the required minimum contribution for participation in the state MFP, but we cannot be sure that this is the actual required minimum contribution overall because we do not know the precise school finance rules in each state. On the other hand, local offset did violate the rules of the program, so districts may have achieved local offset over time by reducing the rate of growth of local revenue; it is easier to do this quickly when the grant is small relative to initial local spending.

${ }^{32}$ Strumpf (1998) uses public spending on administrative overhead as a proxy for bureaucratic power, showing municipalities with stronger bureaucracies exhibit larger flypaper effects; Lutz (2010) finds nearly complete crowd out of education grants in New Hampshire, where voters - rather than bureaucrats - directly determine budgets in town meetings; and Brooks, Phillips and Sinitsyn (2011) show that stickiness increases in city council size.

${ }^{33}$ Bureaucrats in the parent governments of dependent school districts (which do not raise their own revenue) may have more scope and incentive to offset federal grants targeted to education by increasing spending in other policy areas. Because our sample is predominately comprised of independent districts (all districts except in North Carolina and Virginia), we do not examine this source of heterogeneity, nor do we distinguish among alternative (noneducation) uses of funds.
} 
on student outcomes (see Hanushek $(1986,1997)$ ) than on the achievement effects of Title I. ${ }^{34}$ We do, however, present separate estimates for blacks and whites to explore the possible importance of race in the within-district allocation of funds. States discontinued publication of spending by race by the mid-1960s, so we cannot examine this directly. But up to that time, school boards did allocate state funding disproportionately to white schools (Margo, 1990; Reber, 2011), so it would not be surprising if they did the same with federal funding before schools desegregated.

The outcome of interest in our analysis is the high school dropout rate of 18 and 19 year olds. Obtaining data on student outcomes at a local level is difficult for this period. High school dropout can be consistently observed at a local level both before and after Title I in the Decennial Census and is also particularly relevant for the South at this time, as 30 percent of whites and 43 percent of blacks aged 18 and 19 were high school dropouts in 1960. Public-use Census microdata and published Census tabulations are insufficient to construct local dropout rates, so we purchased the necessary tabulations, at the county level, from the Census Bureau. ${ }^{35}$ Throughout, we weight by race-specific county population of 18-19 year olds in 1960, so the estimates represent the effect of Title I-induced expenditure increases for the average student. We exploit the heterogeneity of fiscal response documented above as a source of identification. To set ideas, the first column in Figure IV shows the regression-adjusted relationship between initial child poverty rates and the change in per-pupil current expenditure between 1964 and 1969, separately in counties where all districts had low scope for fiscal offset

\footnotetext{
${ }^{34}$ Several major studies - the Sustaining Effects Study (Carter, 1984) and the Prospects study (Puma et al., 1997) attempt to estimate the effects of participating in Title I programs on student outcomes. Identifying these effects is difficult, given the negative selection of participants by design. See also Borman and D'Agostino (1996), and van der Klaauw (2008).

${ }^{35}$ There are 856 districts represented in the 655 counties in the sample. We restrict attention to counties where districts in our estimation sample represent at least 90 percent of total county enrollment in 1960. Though all discussion of impact on dropout refers to counties, recall that the relevant fiscal decisions are made at and aggregated from the district level.
} 
(Panel A) and in the remaining counties (Panel B). The underlying regressions were estimated using county aggregates of the district-level finance data and are otherwise similar to the reduced-form specifications that underlie the district-level estimates in Table $\mathrm{V}^{36}$ The dot sizes represent the (relative) size of the county's white population aged 18 to 19 in 1960 to reflect weighting of the regression fit. Consistent with our earlier findings, school spending became much more progressive over the second half of the 1960s in the subsample of counties where the scope for fiscal offset by districts was low. ${ }^{37}$ The finding is similar in the subsample of counties with black populations and weighting by initial county black population, as shown in the first column of Figure V.

If "money mattered,” there should have been greater convergence of poorer counties to richer counties in educational attainment over the 1960s in the subsample of counties where the scope for local offset was low, or where Title I translated into higher spending at a greater rate. We explore this in the second column of each figure using the same specification as in the first column but replacing the dependent variable with the 1960 to 1970 change in high school dropout rates of 18 and 19 year olds. For whites (Figure IV), the reduction in high school dropout over the 1960s was much larger in poorer counties than richer counties in the subsample with low scope for offset (Panel A), but not elsewhere (Panel B), suggesting that Title I-induced spending increases improved white educational outcomes. This was not the case for blacks, however (Figure V).

In Table VI, we present TSLS estimates of the effects of changes in current expenditure on changes in dropout, instrumenting for the change in per-pupil current expenditure with the

\footnotetext{
${ }^{36}$ The specification also includes the 1960 race-specific dropout rate of 18-19 year olds (also interacted with the low scope for offset indicator) to account for the possibility that the trend in dropout rate depended on the starting point. We unfortunately cannot examine trends in dropout at the county level during the 1950s. County aggregates were generated from all district-level data weighting by 1960 district enrollment.

${ }^{37}$ The difference across the two groups in the change in the poverty gradient in spending is statistically significant (Appendix Table I).
} 
interaction of 1960 child poverty with the low scope for offset indicator. ${ }^{38}$ By using the interaction of the 1960 child poverty rate and the low scope for offset indicator as the excluded instrument, we can allow the 1960 child poverty rate to have an effect on dropout through channels other than educational expenditure. We identify a causal effect of current expenditure on dropout if, in the absence of the program, the relationship between the 1960 child poverty rate and changes in dropout would have been similar in counties with and without low scope for offset. Note that because spending was low and dropout rates high at this time — particularly in the low scope for offset districts where the marginal students affected by the program resided the effects on educational attainment that we identify may be larger than would be expected from modern-day spending increases.

The first column of Table VI presents TSLS estimates for the baseline specification. ${ }^{39}$ The estimates imply that each additional \$100 increase in current expenditure between 1964 and 1969 was associated with a statistically significant 2.9 percentage point reduction in the likelihood of white dropout and an insignificant 1.7 percentage point increase in the likelihood of black dropout over the 1960s. The change in spending was permanent, so these estimates should not be compared to programs involving one-time expenditures. The cohorts in our analysis were exposed to about 5 years of Title I-induced spending increases before we observe their dropout outcomes in 1969. Title I grants were slightly smaller in the early years (and some districts did not receive their grants due to non-compliance with the Civil Rights Act), so these effects

\footnotetext{
${ }^{38}$ This is equivalent to scaling the difference in the poverty coefficients, for high and low scope for offset counties, from the regressions with the change in dropout rates as the dependent variable by the corresponding difference in their poverty coefficients from the regressions with the change in per pupil current expenditure as the dependent variable. Results are qualitatively similar, but somewhat smaller in magnitude, when we define low scope for offset as having an above median ratio of the 1969 Title I grant to 1964 local revenue.

${ }^{39}$ As in Table V, we interact the low scope for offset indicator with most but not all of the controls in the baseline specification. First-stage and reduced-form estimates that correspond to the specification shown in the first column are in Appendix Table I.
} 
correspond to exposure to somewhat less than $\$ 500$ of additional cumulative spending between 1965 and 1969.

It is difficult to compare these estimates to others in the literature, as most existing studies that measure outcomes with educational attainment — studies which, like this one, focus on individuals schooled before 1970 — measure school inputs directly (i.e., with pupil-teacher ratios) rather than with educational expenditure. ${ }^{40}$ We can however think about the magnitudes of the estimates in several ways. First, a back-of-the-envelope cost-benefit analysis focusing solely on labor market returns to an additional year of schooling for whites implies that the value of the social benefits were nearly twice as large as the spending increase (see Appendix B for details). Second, the point estimate for whites implies that Title I explains 30 percent of the 10 percentage point reduction in their high school dropout rate over the decade. ${ }^{41}$ By contrast, the point estimate suggests Title I had an adverse effect on blacks, but using the 95 percent confidence interval, we estimate that at most, Title I can account for 22 percent of the 14 percentage point reduction in black high school dropout over the 1960s.

The estimates are robust to several specification tests. For example, adding more controls to the model reduces precision but does not qualitatively affect the estimates. In column (2), we include changes in transfer payments to the county over the 1960s through other federal programs, including Head Start and Medicaid. In column (3), we also add county aggregates of

\footnotetext{
${ }^{40}$ See, for example, Card and Krueger (1992a, 1992b, 1996) and Ashenfelter, Collins, and Yoon (2006). Such studies find positive effects of measured inputs on educational attainment and wages, but it is difficult to compare the magnitudes to our estimates. Reber (2010) estimates the effects of desegregation-induced changes in spending on educational attainment for blacks and finds somewhat smaller effects. On the other hand, existing work estimating the effects of educational spending tends to use test scores as the educational outcome of interest (Hanushek, 1997).

${ }^{41}$ These calculations scale up the coefficient on the change in per-pupil funding (or its upper bound) in column (1) of Table VI by the predicted change in per-pupil spending from Title I for the average child, then divide by the (weighted) mean of the dependent variable. The predicted change in per-pupil spending from Title I is calculated separately by race, weighting by the 1960 race-specific population of 18 and 19 year olds and controlling for their dropout rate.
} 
the two measures of desegregation as of 1970 introduced above and of the 1970 white private school enrollment rate. Perhaps more compelling, we see no effect of spending on high school dropout rates of an older group, whose secondary education would have been completed prior to 1965. We show this in column (5), using as a dependent variable the change in the percent of a county's whites (Panel A) and blacks (Panel B) aged 25 and older without a high school degree. Presumably, unobserved shocks to educational attainment in the county population - through migration, for example - would have affected this older age group as well.

Thus, the estimates suggest that whites benefited from Title I-induced changes in educational expenditure, but blacks did not. The estimates are sufficiently imprecise that we cannot reject moderate beneficial effects for blacks, but we reject that the effects are the same for the two groups. A larger effect for whites is plausible, given that even nominal targeting of Title I funding to the most disadvantaged students within districts was weak at the time (Martin and McClure, 1969), and that substantial desegregation occurred only after 1968, so districts may have been able to continue targeting resources disproportionately to white students, as they had done at least through the 1950s (Margo, 1990). If Title I-induced increases in spending were directed to whites, it should be the case that whites in districts with more blacks benefited more from Title I, as there would have been more Title I funding to divert to a smaller group of whites. When we test whether the effect of changes in spending on dropout depended on the black enrollment share, in column (4), the estimates are in the expected direction but quite imprecise.

The estimates in Table VI nevertheless point to some benefit for blacks of desegregationrelated changes in school resources over the 1960s, consistent with the work of Reber (2010, 2011). Districts with higher black enrollment shares in 1960 saw larger increases in per-pupil current expenditure over the second half of the 1960s (Table III), likely because this additional 
funding in blacker districts was needed to "level up" quality in desegregated schools to that previously available only in the white schools. Table VI, Panel B shows that there was a corresponding disproportionate reduction in dropout rates among blacks in blacker counties. Under the relatively strong assumption that the effects of initial black enrollment share on black dropout worked only through such desegregation-related increases in spending, these estimates imply a 3.75 percentage point greater reduction in black dropout for each additional $\$ 100$ increase in per-pupil current expenditure growth. ${ }^{42}$ Increases in school spending through this alternative channel would account for about 43 percent (6.1 percentage points) of the overall decline in dropout among blacks during the 1960s. In this historical context, policies specifically targeted to blacks, like school desegregation, appear to have been more effective in helping blacks than policies targeted to poor children. ${ }^{43}$

\section{Discussion}

This paper examines the impacts of the introduction of Title I of the Elementary and Secondary Education Act in the South. Combining variation in the program's intensity across school districts with the timing of its introduction in 1965, we find evidence of an important role for Title I in increasing the level and progressivity of funding for Southern schools during the 1960s. School districts responded to the influx of Title I funding by significantly reducing their own fiscal effort, but only where institutions permitted this response. "Money mattered,” but

\footnotetext{
${ }^{42}$ The 3.75 figure comes from scaling down the coefficient on 1960 black enrollment share in Table VI, Panel B column (1) by the coefficient on 1960 black enrollment share in a regression for the 1964 to 1969 change in per pupil expenditure that weights by the 1960 population of black 18-19 year olds and includes their 1960 dropout rate as a control (\$387). We arrive at the 6.1 percentage point figure as $3.75 \times 3.87 \times 0.42$, where 0.42 is the initial black share for the average black 18 or 19 year old in 1960 .

${ }^{43}$ A growing literature examining the effects of policy efforts to narrow black-white school quality gaps and desegregate schools consistently concludes that such programs were beneficial for blacks on a variety of outcomes, including educational attainment. See, for example, Reber (2010), Johnson (2011), Card and Krueger (1992a), Lutz (2011), Ashenfelter, Collins, and Yoon (2006), Guryan (2004), and Weiner, Lutz, and Ludwig (2009).
} 
only in places where the introduction of Title I increased spending on education and only for whites. ${ }^{44}$ Despite this, the program appears to have been cost-effective overall.

Our analysis makes important contributions to both our understanding of how intergovernmental grants operate and the effects of Title I, but necessarily falls short of a full assessment of the legacy of Title I. The program likely had other benefits - on other educational or social outcomes, on other cohorts, or in the increased consumption of other goods that crowd out represents - that are not easily quantified. Title I likely also had effects through other channels, particularly for blacks. Combined with provisions of the Civil Rights Act prohibiting the receipt of federal funds by discriminating school districts, Title I promoted voluntary desegregation and reduced the burden on the federal courts in dismantling segregation (Cascio, et al. 2010; Rosenberg, 1991). The spending response to desegregation, which also benefited blacks, might have been smaller in the absence of the influx of Title I funds (Reber, 2011).

Our findings illuminate the usefulness of examining the impacts of intergovernmental grants on a jurisdiction's finances alongside any evaluation of its impacts on the ultimate outcome of interest and the importance of institutions in mediating these effects. In particular, failure to find effects of grants on outcomes of interest should not necessarily be taken as evidence that resources do not matter if the institutional context is one where grants do not translate to higher spending. Grants should only affect outcomes where circumstances constrain localities to use the funds on the targeted good. Indeed, the introduction of Title I only improved education where it increased education spending.

\footnotetext{
${ }^{44}$ Our findings are in contrast to the existing literature on Title I, which has concluded the program is largely ineffective. However, we ask a different question by estimating returns to increases in education spending induced by Title I for all students in a district, rather than comparing outcomes of participants in whatever was called a Title I program at a particular point in time to those for non-participants (as in Carter, 1984; Puma et al., 1997).
} 


\section{References}

Almond, Douglas, Kenneth Chay, and Michael Greenstone. 2006. “Civil Rights, the War on Poverty, and Black-White Convergence in Infant Mortality in the Rural South and Mississippi.” MIT Department of Economics Working Paper no. 07-04.

Almond, Douglas, Hilary Hoynes, and Diane Whitmore Schanzenbach. 2011. "Inside the War on Poverty: The Impact of the Food Stamp Program on Birth Outcomes.” Review of Economics and Statistics, XCIII (2):387-403.

Alt, James E. 1995. "Persistence and Change in Southern Voter Registration Patterns, 19721990.” In Classifying by Race, ed. Paul E. Peterson, 313-332. Princeton N.J.: Princeton University Press.

Ashenfelter, Orley, William Collins, and Albert Yoon. 2006. “Evaluating the Role of Brown v. Board of Education in School Equalization, Desegregation, and the Income of African Americans.” American Law and Economics Review, 8(2):213-248.

Bailey, Stephen K. and Edith K. Mosher. 1968. ESEA: The Office of Education Administers a Law. Syracuse, NY: Syracuse University Press.

Baicker, Katherine and Douglas Staiger. 2005. "Fiscal Shenanigans, Targeted Federal Health Care Funds, and Patient Mortality.” Quarterly Journal of Economics, 120(1):345-386.

Baum-Snow, Nathaniel and Byron F. Lutz. Forthcoming.“School Desegregation, School Choice and Changes in Residential Location Patterns by Race.” American Economic Review.

Borman, Geoffrey D. and Jerome V. D'Agostino. 1996. “Title I and Student Achievement: A Meta-Analysis of Federal Evaluation Results.” Educational Evaluation and Policy Analysis, 18(4): 309-26. 
Bradford, David F. and Wallace E. Oates. 1971. “The Analysis of Revenue Sharing in a New Approach to Collective Fiscal Decisions.” Quarterly Journal of Economics, 85(3):416439.

Brooks, Leah and Justin Phillips. 2010. “An Institutional Explanation for the Stickiness of Federal Grants.” Journal of Law, Economics and Organization, 26(2):243-264.

Brooks, Leah, Justin Phillips, and Maxim Sinitsyn. 2011. “The Cabals of a Few or the Confusion of a Multitude: The Institutional Trade-off between Representation and Governance.” American Economic Journal: Economic Policy, 3(1):1-24.

Card, David and Alan B. Krueger. 1996. “School Resources and Student Outcomes: An Overview of the Literature and New Evidence from North and South Carolina.” The Journal of Economic Perspectives, 10(4): 31-50.

Card, David and Alan B. Krueger. 1992a. "School Quality and Black-White Relative Earnings: A Direct Assessment.” Quarterly Journal of Economics, 107:151-200.

Card, David and Alan B. Krueger. 1992b. “Does School Quality Matter? Returns to Education and the Characteristics of Public Schools in the United States.” The Journal of Political Economy, 100(1):1-40.

Card, David and A. Abigail Payne. 2002. “School Finance Reform, the Distribution of School Spending, and the Distribution of Student Test Scores.” Journal of Public Economics 83: 49-82.

Carter, Launor F. 1984. “The Sustaining Effects Study of Compensatory and Elementary Education.” Educational Researcher, 13(7):4-13.

Cascio, Elizabeth, Nora Gordon, Ethan Lewis, Sarah Reber. 2008. "From Brown to Busing.” Journal of Urban Economics, 64(2):296-325. 
Cascio, Elizabeth, Nora Gordon, Ethan Lewis, and Sarah Reber. 2010. "Paying for Progress: Conditional Grants and the Desegregation of Southern Public Schools.” Quarterly Journal of Economics, 125(1):445-482.

Clark, Melissa A. 2003. “Education reform, redistribution, and student achievement: Evidence from the Kentucky Education Reform Act.” PhD diss. chapter, Princeton University.

Clotfelter, Charles T. 1976. “School Desegregation, 'Tipping' and Private School Enrollment.” Journal of Human Resources, 22:29-50.

Cohen, David K. and Susan L. Moffitt. 2009. The Ordeal of Equality: Did Federal Regulation Fix the Schools? Cambridge, Mass.: Harvard University Press.

Feldstein, Martin S. 1978. "The Effect of a Differential Add-on Grant: Title I and Local Education Spending.” Journal of Human Resources, 13(4):443-58.

Finkelstein, Amy. 2007. "The Aggregate Effects of Health Insurance: Evidence from the Introduction of Medicare.” Quarterly Journal of Economics, 122(3):1-37.

Fisher, Ronald and Leslie Papke. 2000. “Local Government Responses to Education Grants.” National Tax Journal, 53(1):153-168.

Goldin, Claudia and Lawrence F. Katz. 2008. The Race between Education and Technology. Cambridge, MA: Harvard University Press.

Gordon, Nora. 2004. “Do Federal Grants Boost School Spending? Evidence from Title I.” Journal of Public Economics, 88(9-10):1771-1792.

Guryan, Jonathan. 2004. “Desegregation and Black Dropout Rates.” American Economic Review, 94(4): 919-943. 
Guryan, Jonathan. 2001. “Does Money Matter? Regression Discontinuity Estimates from Education Finance Reform in Massachusetts.” NBER Working Paper 8269.

Hanushek, Eric A. 1997. “Assessing the Effects of School Resources on Student Performance: An Update.” Educational Evaluation and Policy Analysis, 19(2):141-164

Hanushek, Eric A. 1986. "The Economics of Schooling. Production and Efficiency in Public Schools.” Journal of Economic Literature, 49(3):1141-1177.

Hines, James R. and Richard H. Thaler. 1995. “Anomalies: The Flypaper Effect.” Journal of Economic Perspectives, 9(4):217-226.

Hoxby, Caroline. 2001. “All School Finance Equalizations are not Created Equal.” Quarterly Journal of Economics, 116(4):1189-1231.

Hoynes, Hilary and Diane Schanzenbach. 2009. “Consumption Responses to In-Kind Transfers: Evidence from the Introduction of the Food Stamp Program.” American Economic Journal: Applied Economics, 1(4):109-139.

Johnson, Rucker C. 2011. "Long-run Impacts of School Desegregation and School Quality on Adult Attainments.” NBER working paper 16664.

Knight, Brian. 2002. "Endogenous Federal Grants and Crowd-out of State Government Spending: Theory and Evidence from the Federal Highway Aid Program.” American Economic Review, 92(1):71-92.

Ludwig, Jens and Miller, Douglas L. 2007. “Does Head Start Improve Children's Life Chances? Evidence from a Regression Discontinuity Design.” The Quarterly Journal of Economics, 122(1):159-208.

Lutz, Byron. 2011. “The End of Court-Ordered Desegregation.” American Economic Journal: Economic Policy, 3(2):130-68. 
Lutz, Byron. 2010. “Taxation with Representation: Intergovernmental Grants in a Plebiscite Democracy.” Review of Economics and Statistics, 92(2):316-332.

Margo, Robert A. 1990. Race and Schooling in the South, 1880-1950: An Economic History. Chicago: University of Chicago Press.

Martin, Ruby and Phyllis McClure. 1969. Title I of ESEA: Is it Helping Poor Children? Washington, DC.: National Association for the Advancement of Colored People, New York, NY and Washington Research Project.

Musgrave, Robert A. 1959. The Theory of Public Finance: a Study in Political Economy. New York: McGraw-Hill.

Oates, Wallace E. 1999. “An Essay on Fiscal Federalism.” Journal of Economic Literature, 37(3), 1120-1149.

Oates, Wallace E. 1972. Fiscal Federalism. New York: Harcourt, Brace, Jovanovich.

Orfield, Gary. 2000. “The 1964 Civil Rights Act and American Education.” In Legacies of the 1964 Civil Rights Act, ed. Bernard Groffman. Charlottesville and London: University of Virginia Press.

Papke, Leslie. 2008. “The Effects of Changes in Michigan’s School Finance System.” Public Finance Review, 36(4):456-74.

Papke, Leslie. 2005. “The Effects of Spending on Test Pass Rates: Evidence from Michigan.” Journal of Public Economics, 89:821-39.

Puma, Michael J., Nancy Karweit, Cristofer Price, Anne Ricciuti, William Thompson and Michael Vaden-Kiernan. 1997. Prospects: Student Outcomes. Final Report. Washington, D.C.: U.S. Department of Education, Planning and Evaluation Service. 
Reber, Sarah J. 2010. "Desegregation and Educational Attainment for Blacks.” Journal of Human Resources, 45(4): 893-914.

Reber, Sarah J. 2011. "From Separate and Unequal to Integrated and Equal? School Desegregation and School Finance in Louisiana." Review of Economics and Statistics, 93(2): 416-435.

Rosenberg, Gerald N. 1991. The Hollow Hope: Can Courts Bring About Social Change? Chicago: University of Chicago Press.

Roy, Joydeep. 2011. “Impact of School Finance Reform on Resource Equalization and Academic Performance: Evidence from Michigan.” Education Finance and Policy, 6(2):137-167.

Roza, Marguerite. 2010. Educational Economics: Where Do School Funds Go? Washington, DC.; Urban Institute Press.

Strumpf, Koleman. 1998. “A Predictive Index for the Flypaper Effect.” Journal of Public Economics, 69:389-412.

U.S. Commission on Civil Rights. 1968. "Political Participation: A Study of the Participation of Negroes in the Electoral and Political Processes in 10 Southern States Since Passage of the Voting Rights Act of 1965.” Washington, D.C.: U.S. Government Printing Office.

U.S. Department of Health, Education and Welfare, Office of Education. 1969. History of Title I ESEA. Washington, DC.

Van der Klaauw, Wilbert. 2008. "Breaking the Link between Poverty and Low Student Achievement: An Evaluation of Title I.” Journal of Econometrics 142(2):731-756. Weiner, David A., Byron F. Lutz, Jens Ludwig. 2009. “Desegregation and Crime.” NBER Working Paper 15380. 
Table I. Descriptive Statistics: Dependent Variables

\begin{tabular}{|c|c|c|c|c|c|}
\hline & \multicolumn{3}{|c|}{ Level } & \multicolumn{2}{|c|}{ Change } \\
\hline & $\begin{array}{c}1961 \\
(1)\end{array}$ & $\begin{array}{c}1964 \\
(2)\end{array}$ & $\begin{array}{c}1969 \\
(3)\end{array}$ & $\begin{array}{c}1961 \text { to } 1964 \\
\text { (4) }\end{array}$ & $\begin{array}{c}1964 \text { to } 1969 \\
\text { (5) }\end{array}$ \\
\hline Per-pupil federal revenue & $\begin{array}{c}48.12 \\
(63.40)\end{array}$ & $\begin{array}{c}65.19 \\
(74.43)\end{array}$ & $\begin{array}{c}484.90 \\
(262.51)\end{array}$ & $\begin{array}{c}17.07 \\
(34.99)\end{array}$ & $\begin{array}{c}419.71 \\
(270.25)\end{array}$ \\
\hline Per-pupil state revenue & $\begin{array}{l}1,191.38 \\
(355.36)\end{array}$ & $\begin{array}{l}1,320.77 \\
(354.39)\end{array}$ & $\begin{array}{l}1,805.77 \\
(430.02)\end{array}$ & $\begin{array}{l}129.40 \\
(96.07)\end{array}$ & $\begin{array}{c}485.00 \\
(231.12)\end{array}$ \\
\hline Per-pupil local revenue & $\begin{array}{c}450.38 \\
(349.20)\end{array}$ & $\begin{array}{c}511.66 \\
(403.78)\end{array}$ & $\begin{array}{c}838.29 \\
(601.47)\end{array}$ & $\begin{array}{c}61.28 \\
(116.32)\end{array}$ & $\begin{array}{l}326.63 \\
(288.68)\end{array}$ \\
\hline Per-pupil current expenditure & $\begin{array}{l}1,682.35 \\
(456.66)\end{array}$ & $\begin{array}{l}1,910.49 \\
(468.12)\end{array}$ & $\begin{array}{l}2,828.63 \\
(522.20)\end{array}$ & $\begin{array}{c}228.13 \\
(214.99)\end{array}$ & $\begin{array}{c}918.14 \\
(421.78)\end{array}$ \\
\hline
\end{tabular}

Notes: All figures are in real 2009 dollars. Standard deviations are in parentheses. Sample consists of 922 school districts in 9 southern states: Alabama, Florida, Georgia, Louisiana, Mississippi, North Carolina, South Carolina, Tennessee, and Virginia. See Appendix A for description of estimation sample. 
Table II. Descriptive Statistics: Independent Variables

\begin{tabular}{lccc}
\hline \hline & $\begin{array}{c}\text { Mean } \\
(1)\end{array}$ & $\begin{array}{c}\text { Std. dev. } \\
(2)\end{array}$ & $\begin{array}{c}\text { Obs. } \\
\text { (3) }\end{array}$ \\
\hline Child poverty rate, 1960 & 0.32 & 0.17 & 922 \\
State factor in Title I grant, 1969 & 954 & 6.11 & 922 \\
Black share in enrollment, 1960 & 0.32 & 0.22 & 922 \\
District enrollment, 1960 & 6,921 & 11,801 & 922 \\
Poorest 300 counties, 1960 (=1) & 0.24 & 0.43 & 922 \\
Percent voting for Thurmond, 1948 & 34 & 30 & 922 \\
Black voter registration rate, early 1960s (percent) & 28 & 24 & 824 \\
White private school enrollment share, 1970 & & & \\
Black/white dissimilarity index, 1970 & 0.04 & 0.07 & 901 \\
District under court supervision, 1970 & 0.28 & 0.22 & 864 \\
\hline
\end{tabular}

Notes: All dollar figures are in real (2009) terms. Sample consists of school districts in 9 southern states: Alabama, Florida, Georgia, Louisiana, Mississippi, North Carolina, South Carolina, Tennessee, and Virginia. See Appendix A for description of estimation sample. 
Table III. Reduced-Form and TSLS Estimates of the Fiscal Response to Title I

\begin{tabular}{|c|c|c|c|}
\hline & \multicolumn{2}{|c|}{1964 to 1969} & \multirow{2}{*}{$\begin{array}{c}1961 \text { to } 1964 \\
\text { Reduced Form } \\
\end{array}$} \\
\hline & Reduced Form & TSLS & \\
\hline & $(1)$ & $(2)$ & (3) \\
\hline & \multicolumn{3}{|c|}{ A. Per-pupil Federal Revenue } \\
\hline \multirow[t]{2}{*}{ Child Poverty Rate, 1960} & $929.2^{* * *}$ & -- & 10.88 \\
\hline & $(73.50)$ & -- & (7.708) \\
\hline \multirow[t]{3}{*}{ Fraction Black, 1960} & 73.43 & -- & $-7.892 *$ \\
\hline & $(45.46)$ & -- & $(4.606)$ \\
\hline & \multicolumn{3}{|c|}{ B. Per-pupil Current Expenditure } \\
\hline \multirow[t]{2}{*}{ Child Poverty Rate, 1960} & $424.6 * * *$ & & -54.42 \\
\hline & $(107.5)$ & & (56.15) \\
\hline \multirow[t]{2}{*}{$\Delta$ Per-pupil Federal Revenue } & & $0.457 * * *$ & \\
\hline & & $(0.0994)$ & \\
\hline \multirow[t]{3}{*}{ Fraction Black, 1960} & $371.6 * * *$ & $338.1^{* * *}$ & -17.95 \\
\hline & $(79.20)$ & $(75.01)$ & $(47.63)$ \\
\hline & \multicolumn{3}{|c|}{ C. Per-pupil State Revenue } \\
\hline \multirow[t]{2}{*}{ Child Poverty Rate, 1960} & 45.24 & & $59.84^{* *}$ \\
\hline & $(46.20)$ & & $(27.73)$ \\
\hline \multirow[t]{2}{*}{$\Delta$ Per-pupil Federal Revenue } & & 0.0487 & \\
\hline & & $(0.0491)$ & \\
\hline \multirow[t]{3}{*}{ Fraction Black, 1960} & $58.92 *$ & 55.34 & 2.227 \\
\hline & $(35.65)$ & $(37.27)$ & $(20.66)$ \\
\hline & \multicolumn{3}{|c|}{ D. Per-pupil Local Revenue } \\
\hline \multirow[t]{2}{*}{ Child Poverty Rate, 1960} & $-306.7 * * *$ & & $-63.36 *$ \\
\hline & $(63.78)$ & & $(33.48)$ \\
\hline \multirow[t]{2}{*}{$\Delta$ Per-pupil Federal Revenue } & & $-0.330 * * *$ & \\
\hline & & $(0.0733)$ & \\
\hline \multirow[t]{3}{*}{ Fraction Black, 1960} & $124.8^{* * *}$ & $149.1^{* * *}$ & $-35.75 *$ \\
\hline & $(46.22)$ & $(52.16)$ & $(21.30)$ \\
\hline & \multicolumn{3}{|c|}{ E. Per-Pupil Total Revenue less Per-Pupil Current Expenditure } \\
\hline \multirow[t]{2}{*}{ Child Poverty Rate, 1960} & $243.2 * * *$ & & 61.78 \\
\hline & (82.83) & & $(58.20)$ \\
\hline \multirow[t]{2}{*}{$\Delta$ Per-pupil Federal Revenue } & & $0.262^{* * *}$ & \\
\hline & & $(0.0863)$ & \\
\hline \multirow[t]{2}{*}{ Fraction Black, 1960} & $-114.4^{*}$ & $-133.7 * *$ & -23.46 \\
\hline & $(65.04)$ & $(65.71)$ & $(48.56)$ \\
\hline First-stage Partial $F$-stat on instrument & & 159.9 & \\
\hline Number of districts & 922 & 922 & 922 \\
\hline
\end{tabular}

Notes: All dollar figures are in real (2009) terms. All specifications include as controls state dummies, 1960 black enrollment share, $\ln (1960$ district enrollment), an indicator that the district is in one of the 300 poorest counties in 1960 and indicators for quintiles of the Thurmond vote share. The TSLS regressions in column (2) use the 1960 child poverty rate as an instrument for the change in per-pupil federal revenue. Standard errors (in parentheses) are clustered on county. ***,**, * represent statistical significance at the 1,5 , and 10 percent levels, respectively. 
Table IV. Sensitivity of the TSLS Estimates of the Long-Run Fiscal Response to Title I

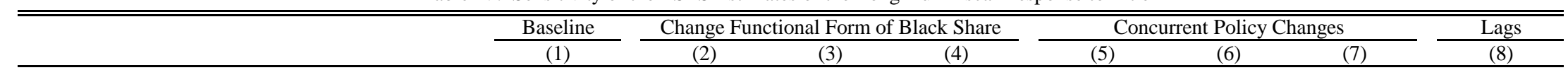

(1)

(2)

A. $\Delta$ Per-pupil Current Expenditure

$\Delta$ Per-pupil Federal Revenue

Root MSE

$\Delta$ Per-pupil Federal Revenue

Root MSE

$\Delta$ Per-pupil Federal Revenue

\section{Root MSE}

First-stage Partial $F$-stat on Instrument

Number of districts

Controls:

Black share in enrollment, 1960

$\ln$ (district enrollment, 1960)

Poorest 300 counties indicator

Thurmond vote, 1948 (quintile dummies)

State dummies

$\mathrm{x}$ black share in enr, 1960

$x \ln$ (district enr, 1960)

Deciles of black share in enrollment, 1960

School segregation measures, 1970

White private school enrollment share, 1970

Voter Registration, 1960

Change spending on other public programs

Pre-program change in dependent variable

$\begin{array}{lcc}0.457 * * * & 0.504^{* * *} & 0.460^{* * *} \\ (0.0994) & (0.0794) & (0.0820) \\ 293.6 & 292.6 & 291.2\end{array}$

$0.522 * * *$
$(0.0942)$
293.2

$0.491^{* * *}$
$(0.101)$
292.7

$0.480 * * *$
$(0.110)$
297.7

$0.456 * * *$

(0.103)

$0.425^{* * *}$

$293.2 \quad 292.7$

B. $\Delta$ Per-pupil State Revenue

$\begin{array}{ccc}0.0487 & 0.0779 * & 0.0470 \\ (0.0491) & (0.0408) & (0.0384) \\ 144.6 & 144.5 & 134.6\end{array}$

0.019

0.0705
$(0.0491)$

0.0577

(0.0565)

0.0455

144.2

142.4

148.5

$(0.0515)$

144.2

0.0613

C. $\Delta$ Per-pupil Local Revenue

$\begin{array}{ccc}-0.330 * * * & -0.323 * * * & -0.332 * * * \\ (0.0733) & (0.0585) & (0.0601) \\ 218.8 & 218.1 & 215.6 \\ & & \\ 159.9 & 232.9 & 243.0 \\ 922 & 922 & 922\end{array}$

$\begin{array}{cc}-0.284 * * * & -0.306 * * * \\ (0.0669) & (0.0741)\end{array}$

$-0.299 * * *$

$(0.0780)$

$(0.0741)$

218.9

$-0.322 * * *$

$(0.0749)$

217.5

$-0.345^{* * *}$
$(0.0742)$

$216.4 \quad 219.9$

182.1

154.3

121.3

155.6

218.8

\begin{tabular}{|c|c|c|c|}
\hline 32.1 & 154.3 & 121.3 & 155.6 \\
\hline 922 & 856 & 824 & 922 \\
\hline
\end{tabular}

$\begin{array}{lllllll}X & & & & \\ X & X & X & X & X \\ X & X & X & X & X & X & X \\ X & & X & X & X & X \\ X & & & X & X & X & X\end{array}$

Notes: Each column and panel represents a different TSLS regression. The instrument for the change in per-pupil federal revenue is the 1960 child poverty rate. Changes in fiscal variables correspond to 1964 to 1969 and are in real (2009) dollars. See Appendix A for detailed description of control variables and data sources. Standard errors (in parentheses) are clustered on county. ***, **,* represent statistical significance at the 1,5 , and 10 percent levels, respectively. 
Table V. Heterogeneous Fiscal Responses to Title I

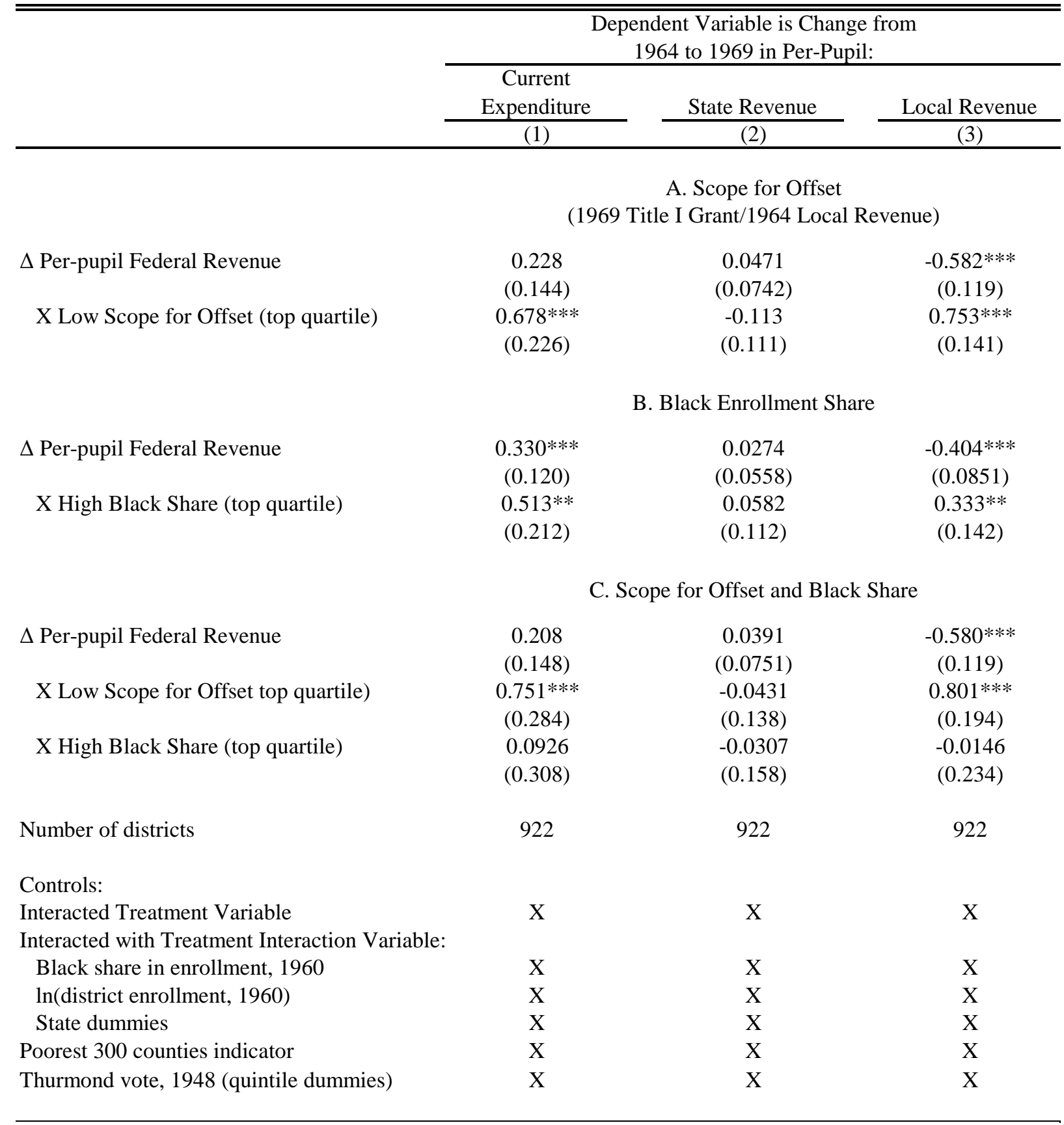

Notes: All dollar figures are in real (2009) terms. Each column and panel presents coefficient estimates from a TSLS regression. Excluded instruments are 1960 poverty rate and 1960 poverty rate interacted with the relevant interacted treatment variable(s) (Panel A: low scope for offset (top quartile of 1969 Title I grant/1964 local revenue), Panel B: high black enrollment share (top quartile), Panel C: low scope for offset and black enrollment share). Standard errors (in parentheses) are clustered on county. $* * *, * *, *$ represent statistical significance at the 1,5 , and 10 percent levels, respectively. 
Table VI. Estimates of the Effect of Changes in Current Expenditure on Dropout Trends

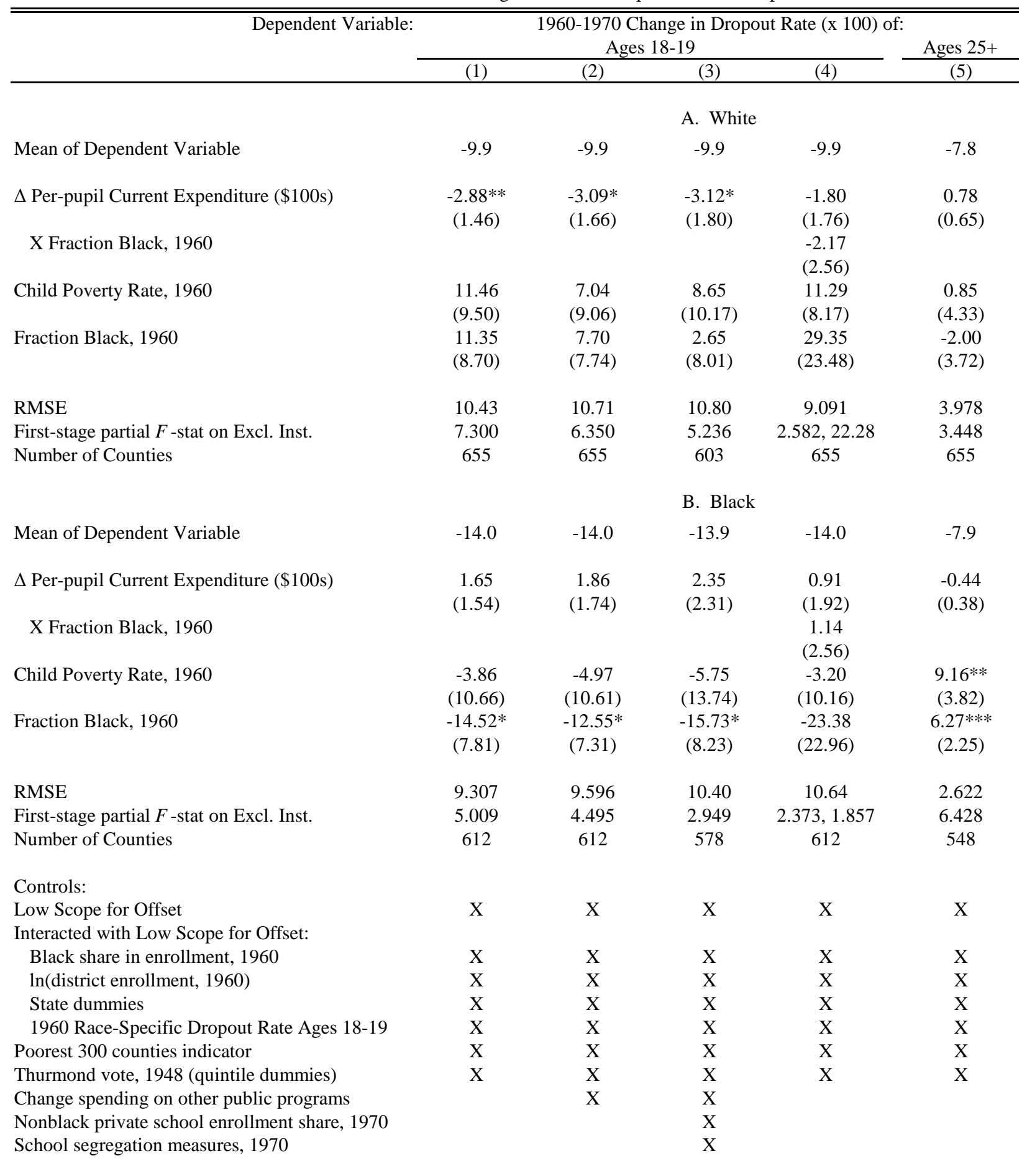

Notes: Each column and panel represents a different TSLS regression, where county is the unit of analysis. In columns (1)(3) and (5), we instrument for the 1964 to 1969 change in per-pupil current expenditure (2009 dollars) with the interaction between the 1960 child poverty rate and the low scope for offset indicator. In column (2), we also instrument for the interaction between the 1964 to 1969 change in per-pupil current expenditure (2009 dollars) and 1960 black enrollment share with the triple interaction between the 1960 child poverty rate, the low scope for offset indicator, and 1960 black enrollment share. Throughout, attention is restricted to counties where districts in our estimation sample represent at least 90 percent of total county enrollment in 1960. County aggregates were generated from the district data weighting by 1960 district enrollment. In cases where not all districts within a county have low scope for offset, we coded the county as not having low scope for offset. Standard errors (in parentheses) are heteroskedasticity robust. ***, **, ${ }^{*}$ represent statistical significance at the 1,5 , and 10 percent levels, respectively. 
Appendix Table 1. Reduced Form Heterogenous Effect Estimates for Current Expenditure and Dropout Rates at the County Level

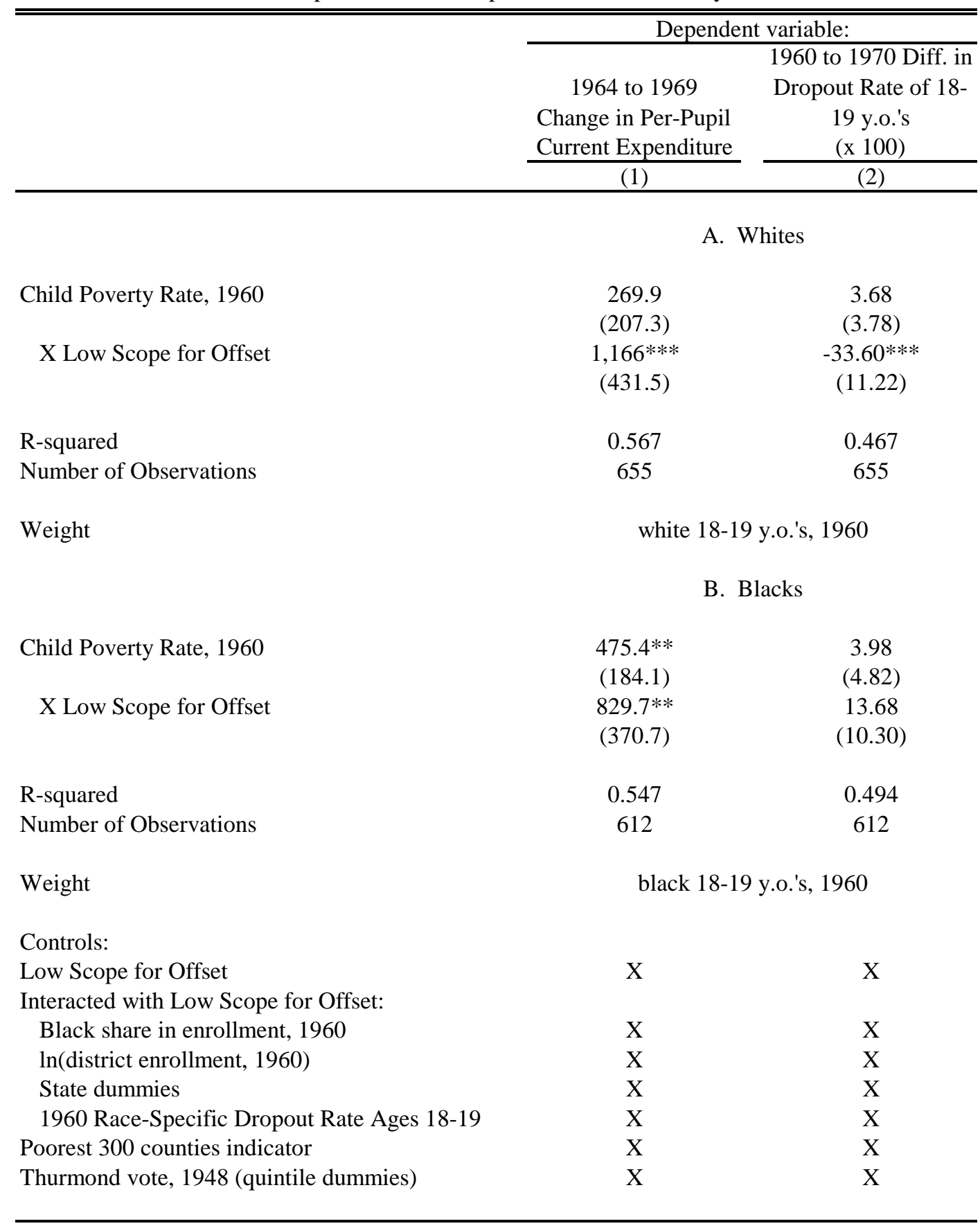

Notes: Each column and panel represent a different regression, where the unit of analysis is a county. We restrict attention to counties where districts in our estimation sample represent at least 90 percent of total county enrollment in 1960. County aggregates of district variables were generated from the district data weighting by 1960 district enrollment. In cases where not all districts within a county have low scope for offset, we coded the county as not having low scope for offset. Standard errors (in parentheses) are heteroskedasticity robust. ***, **, * represent statistical significance at the 1,5 , and 10 percent levels, respectively. 


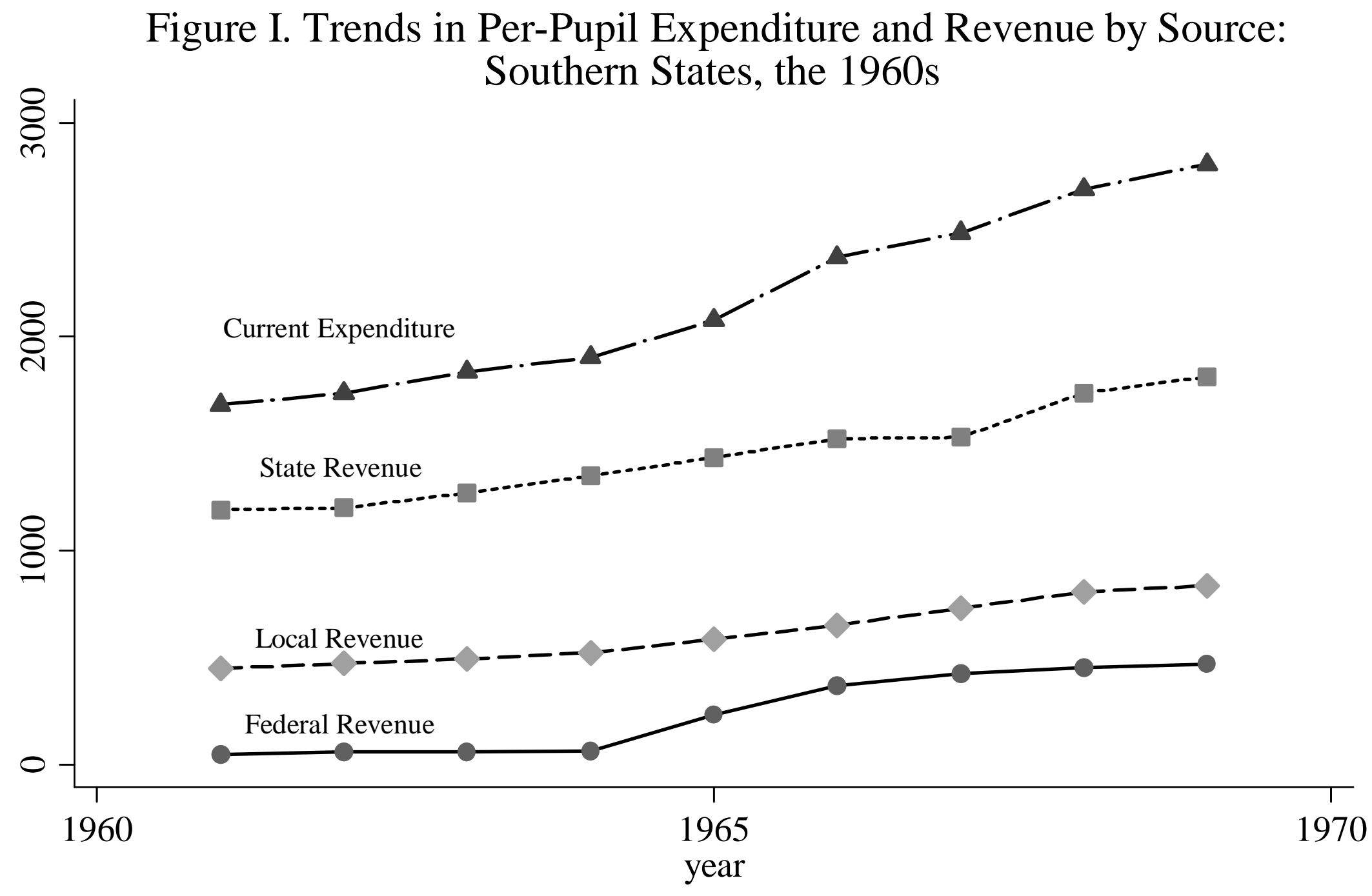

Note: All figures are in 2009 dollars. Unweighted means were calculated from our district-level sample from 9 Southern states: AL, FL, GA, LA, MS, NC, SC, TN, and VA. 


\section{Figure II. Local Government Responses to Title I Grant}

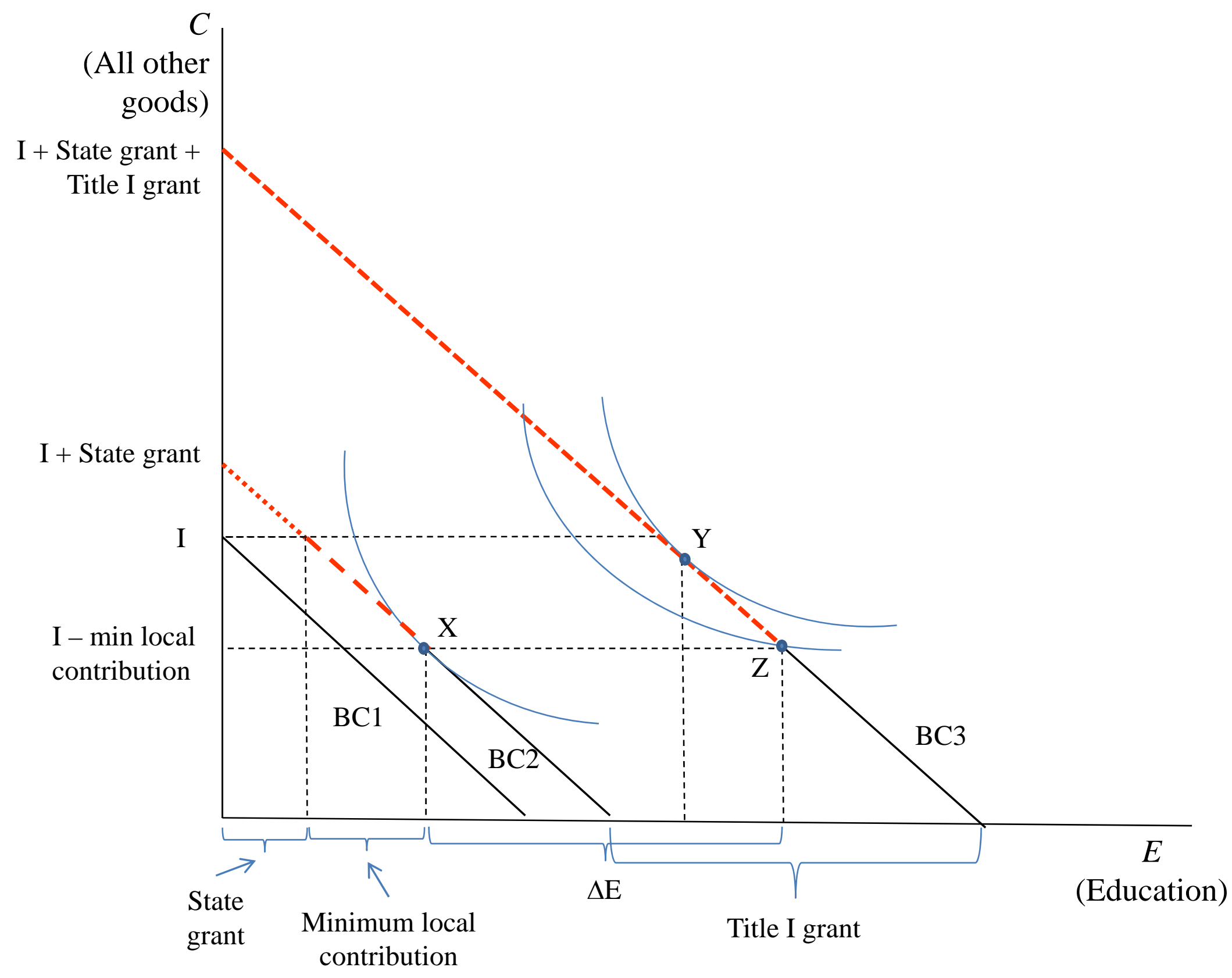




\section{Figure III. Year-by-Year Gradients of District Finance Variables in the 1960 Child Poverty Rate}
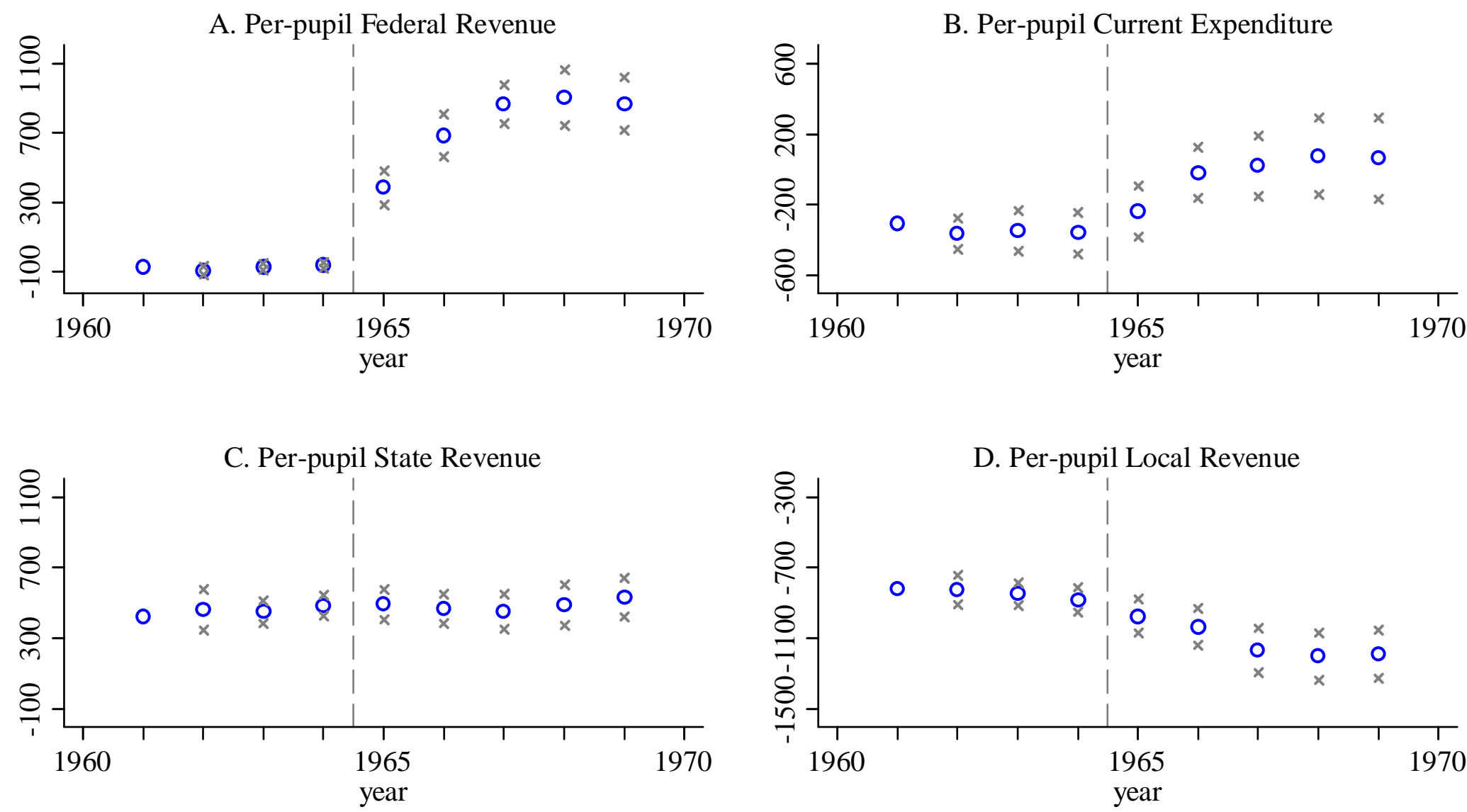

Note: Plotted are the year-specific coefficients and 95\% confidence intervals on the 1960 child poverty rate from regressions on district fixed effects, state by year fixed effects, and the following controls interacted with year dummies: 1960 black share in enrollment, ln(1960 enrollment), dummies for county quintile in 1948 Thurmond vote share, and dummy for among poorest 300 counties in 1960. The omitted year is 1961, and the coefficients are rescaled so that the 1961 coefficient is equal to the cross-sectional poverty gradient in 1961 (with the same controls). 
Figure IV. The 1960 Child Poverty Rate and Differences in Current Expenditure and White Dropout Rates over the 1960s, by Scope for Fiscal Offset

A. Counties with Low Scope for Offset
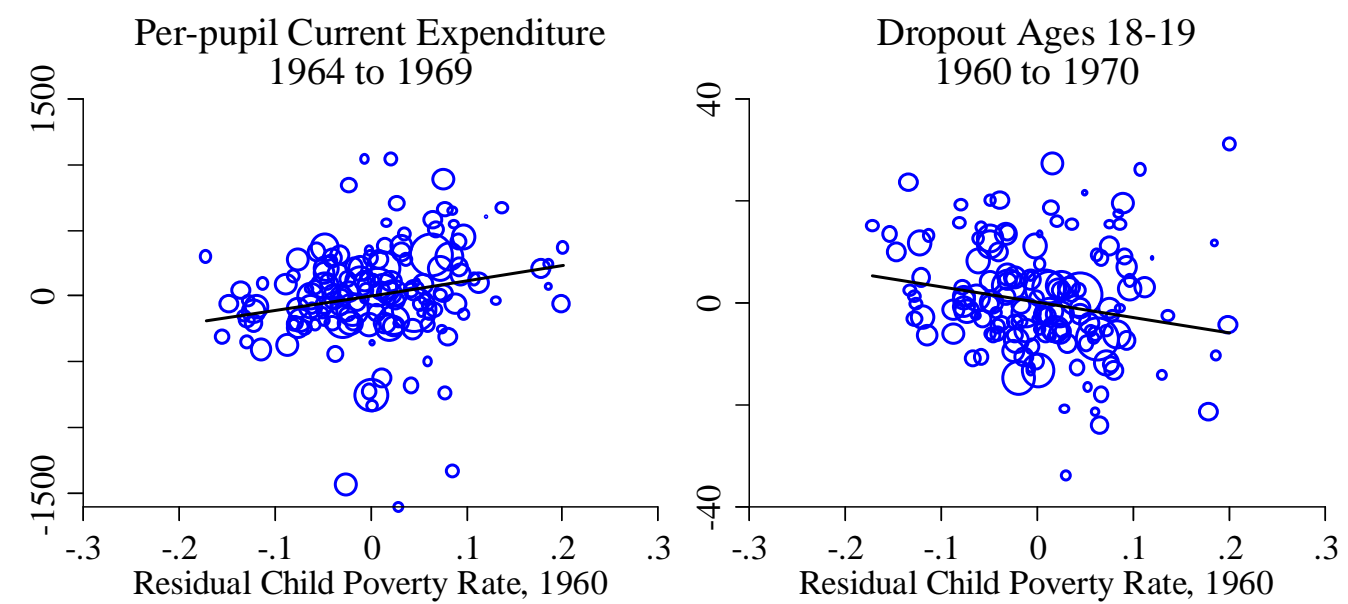

B. Other Counties

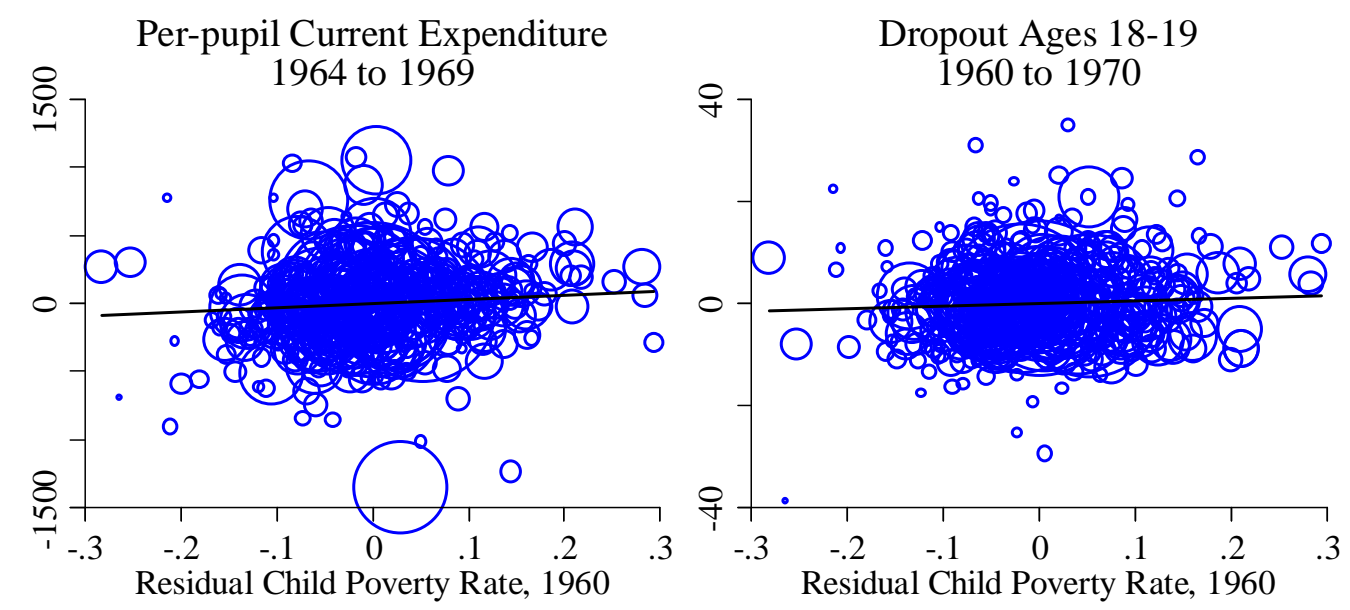

Note: Plotted are residuals from regressions on state dummies, 1960 black share in enrollment, $\ln (1960$ enrollment), dummies for quintile of 1948 Thurmond vote share, dummy for among poorest counties in 1960, the white 1960 dropout rate of 18-19 
Figure V. The 1960 Child Poverty Rate and Differences in Current Expenditure and Black Dropout Rates over the 1960s, by Scope for Fiscal Offset

A. Counties with Low Scope for Offset
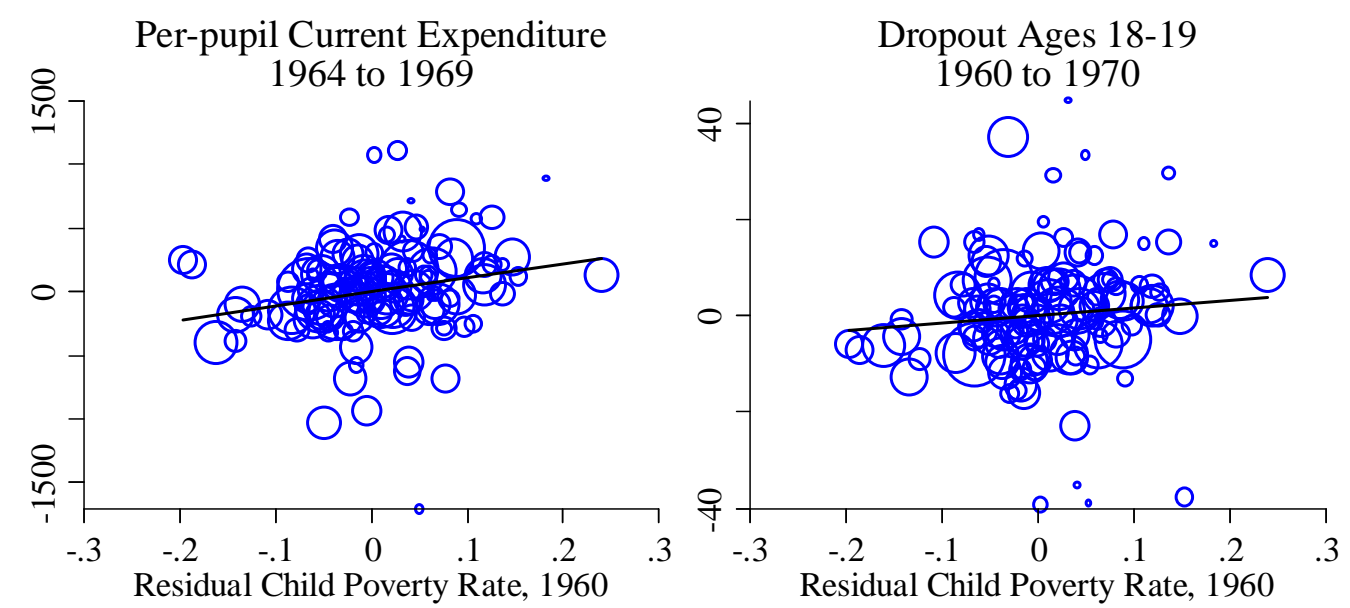

B. Other Counties

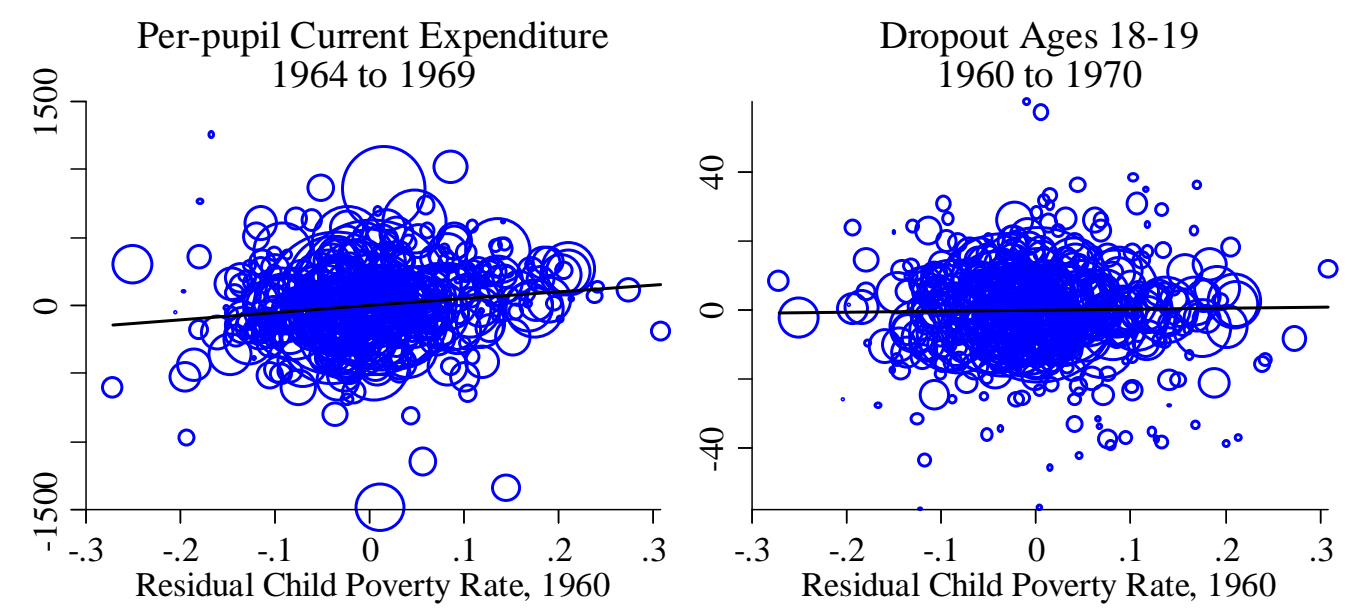

Note: Plotted are residuals from regressions on state dummies, 1960 black share in enrollment, $\ln (1960$ enrollment), dummies for quintile of 1948 Thurmond vote share, dummy for among poorest counties in 1960, the black 1960 dropout rate of $18-19$
year olds. The unit of observation is the county, and regressions are weighted by the black 1960 population of $18-19$ year olds. 


\section{Appendix Figure I. Year-by-Year Gradients of District Finance Variables in the 1960 Child Poverty Rate, by Scope for Offset}
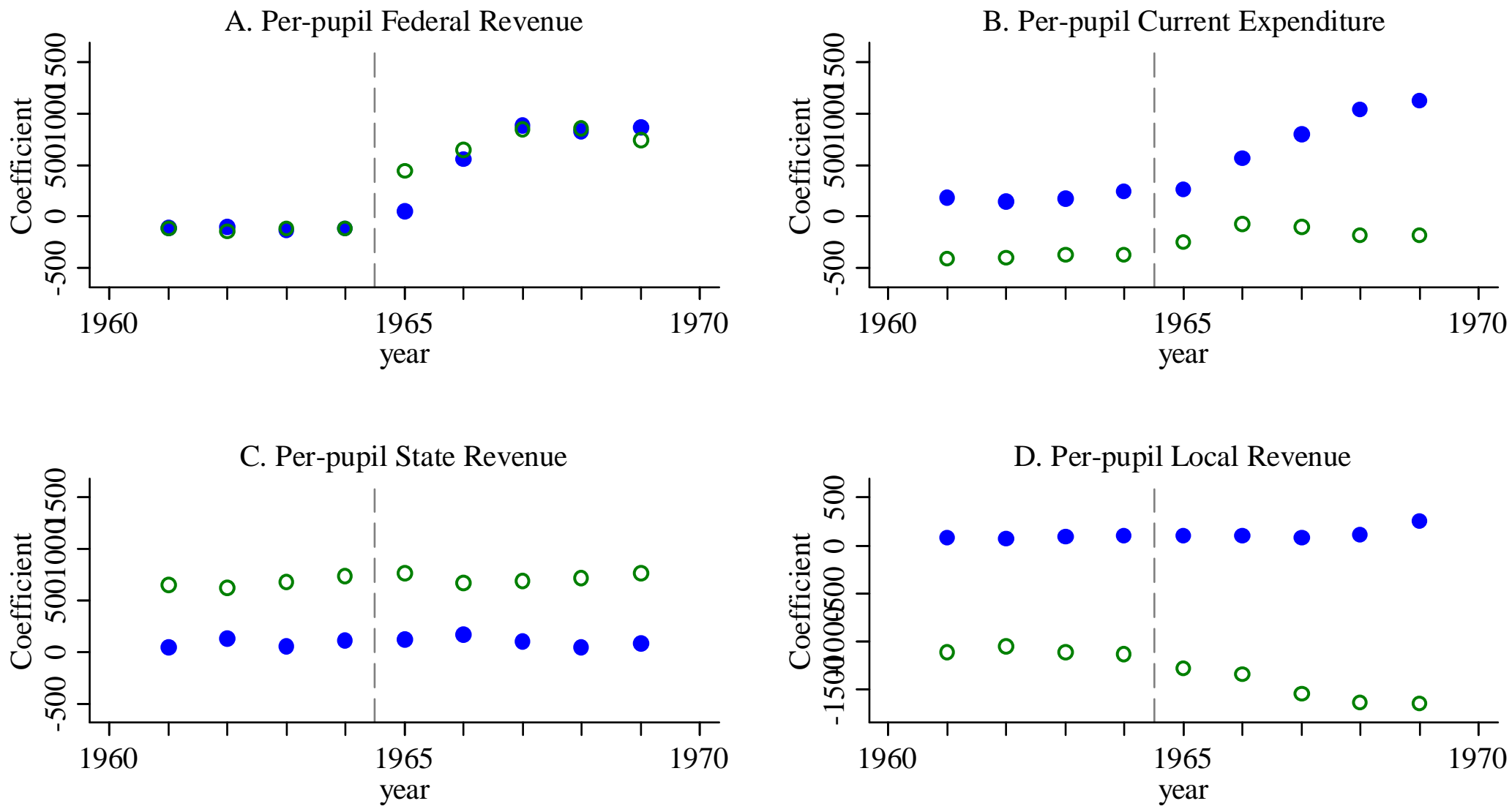

Note: Plotted are the year-specific coefficients on the 1960 child poverty rate from regressions on district fixed effects, state by year fixed effects, and the following controls interacted with year dummies: 1960 black share in enrollment, ln(1960 enrollment), dummies for county quintile in 1948 Thurmond vote share, and dummy for among poorest 300 counties in 1960, estimated separately by scope for local offset. The omitted year is 1961, and the coefficients are rescaled so that the 1961 coefficient is equal to the cross-sectional poverty gradient for the categoy in 1961 (with the same controls). Solid dots represent districts in top quartile of 1969 Title I/1964 local revenue, and hollow dots represent other districts. 


\section{Appendix A: Data}

\section{Sources and Variables}

\section{I.A School Finance and Enrollment Data}

Our analysis of the fiscal impacts of Title I relies on district-level data on current expenditure and revenue by source (local, state, and federal). These data were hand-entered from annual reports of state departments or superintendents of education and are available on an annual basis between 1961 and 1969 with several exceptions: Georgia data are missing in 1964 (use 1963), 1968 (use 1967), and 1969 (use 1970), and Louisiana data are missing in 1967 (use 1966). ${ }^{1}$ Real per-pupil values of the finance variables were created by dividing by total enrollment from the same year, drawn from the same source, then converting to real 2009 dollars using the CPI-U.

\section{I.B High School Dropout Data}

Our analysis of the effects of Title I on educational attainment uses the 1960 to 1970 change in the high school dropout rate of 18 and 19 year olds as the dependent variable. We constructed this outcome using county-level tabulations of population characteristics by single year of age (ages 15 to 19) and race (white, black/African American, other), produced for us by the Census Bureau using the sample detail files from the 1960 and 1970 Censuses. The numerator of the dropout rate in a given Census year is the number of 18 and 19 year residents of a county of a given race who report not being currently enrolled in school and less than twelve years of completed education. The denominator is the total number of 18 and 19 year residents of that county of that race with education reported.

We perform a falsification check using the 1960 to 1970 change in the high school dropout rate of county residents aged 25 and over, which we constructed in a similar fashion using published Census tabulations of the total population (both years) and the non-white population in 1960 and black population in $1970 .^{2}$ Here, the numerator of the dropout rate in a given Census year is the number of residents age 25 and over with less than twelve years of completed education, and the denominator is the total number of residents age 25 and over with education reported. Data for 1960 was hand-entered from Table 83 and Table 87 of U.S. Census (1963). Data for 1970 was downloaded from the National Historical Geographic Information System (Minnesota Population Center, 2004).

\section{I.C Title I Eligibility Data}

Our identification strategy relies on an estimate of initial district eligibility for Title I funds. Title I funding allocations were made at the county level. States then allocated grants to districts

\footnotetext{
${ }^{1}$ Alabama Department of Education (various years), Florida State Superintendent of Public Instruction (various years), Georgia State Department of Education (various years), Mississippi State Department of Education (various years), North Carolina Education Association (various years), South Carolina State Department of Education (various years), State Department of Education of Louisiana (various years), Tennessee Department of Education (various years), Virginia State Board of Education (various years).

${ }^{2}$ Tabulations for the white population are the difference between total and non-white (in 1960) or black (in 1970), when non-white or black is reported, and total, when non-white or black is not reported (due to small population).
} 
within each county. We do not know data sources used for this purpose, but we do observe district-level Title I allocations in the first fall of the program in 1965, t1alloc ${ }_{d, 1965}$ (U.S. Senate, 1967). We also observe county-level counts of 5-17 year olds eligible for Title I in fall 1965, t1elig $_{c, 1965}$ (U.S. Senate, 1965). Using these data, we estimate district counts of Title I eligible child for 1965, telig $_{d, 1965}$ as

$$
\text { t1elig }_{d, 1965} \approx \text { t1elig }_{c, 1965} \times \frac{\text { t1alloc }_{d, 1965}}{\sum_{d \in c} \text { t1alloc }_{d, 1965}}
$$

or with the 1965 county-level eligibles times the share of the 1965 county Title I allocation received by the district. ${ }^{3}$ We then define the "initial" child poverty rate as $t 1 e^{2} i g_{d, 1965} /$ enr $_{d, 1960}$, where $e n r_{d, 1960}$ represents 1960 district enrollment. If the effective poverty rate for distribution of Title I funds (based on current enrollment and current eligibility) were roughly equal to the initial child poverty rate, the change between 1964 and any year from 1965 to 1969 in the coefficient on child_poverty in regressions for per-pupil federal revenue should be equal to the amount received for districts for each eligible child - the "state factor" - in the Title I formula. We collected state factors for 1965-1967 and 1969 from congressional publications (U.S. Senate, 1965, 1967, 1970). ${ }^{4}$

\section{I.D Other District- and County-Level Covariates}

1. 1960 black enrollment share (district): For most states, this variable is constructed from 1960 data on enrollment by race in the school finance publications cited in Section I.A of this Appendix. ${ }^{5}$ We estimated this variable for North Carolina using district-level data from Southern Education Reporting Service (1964, 1966).

2. Thurmond vote share in the 1948 Presidential Election (county): The county-level percent of votes cast for Strom Thurmond in the 1948 Presidential election was drawn from ICPSR Study No. 8611 (Clubb, Flanigan, and Zingale 2006).

3. Poorest Counties in 1960 (county): Data on whether a county was one of the 300 poorest counties in 1960, which was expected to have received special grant-writing assistance for Head Start (Ludwig and Miller, 2007), was generously provided to us by Jens Ludwig and Douglas Miller. The poverty rate used in this determination was also provided to us, and is distinct from (but positively correlated with) that used for dissemination of funds under Title I (see section I.C of the Data Appendix).

\footnotetext{
${ }^{3}$ Note that, in reality, there were two categories of Title I eligibles in 1965: (1) children aged 5 to 17 in families with incomes less than $\$ 2000$ in the 1960 Census; (2) children in families receiving AFDC in excess of $\$ 2000$. We refer to all Title I eligibles as being from group (1) for ease of explanation, as the vast majority of eligibles are in indeed in this group in our sample.

${ }^{4}$ Funding amounts per eligible child were ratably reduced by state-specific multiplicative constants after 1965, when Title I was no longer fully funded.

${ }^{5}$ We use the enrollment measure most consistently reported within the state over time. All states except Georgia and North Carolina report fall enrollment or registration or average daily membership. To make these states' enrollment figures more comparable to those for other states, we multiply the enrollment concept reported (average daily attendance, or ADA) by the statewide average ratio of fall enrollment to ADA reported in U.S. DHEW (1967).
} 
4. 1970 Dissimilarity Index (district): The formula for the dissimilarity index is given by:

$$
\frac{\sum_{i \in d} e n r_{i}\left|\% b l_{i}-\% b l_{d}\right|}{2 \times e n r_{d} \times \% b l_{d} \times\left(1-\% b l_{d}\right)}
$$

where $e n r_{i}$ is total enrollment in school $i$, enr $r_{d}$ is the enrollment in district $d$ (summing across all schools), $\% b l_{i}$ is the percent of total enrollment in school $i$ that is black, and $\% b l_{d}$ is the black enrollment percent in district $d$. It can be interpreted as the share of students who would have had to change schools to replicate the racial composition of the district in each school. We construct a dissimilarity index for all available districts as of 1970 using computer-coded microdata on enrollment by race at the school level from a 1970 survey conducted by the Office for Civil Rights (OCR), housed at UCLA and converted from binary to ascii format by Ben Denckla and Sarah Reber (Denckla and Reber, 2006). Not all districts are represented in this survey, so we lose some districts when including the dissimilarity index as a control. ${ }^{6}$

5. 1970 Court Supervision (district): We classify a district as having a court-supervised desegregation plan in 1970 if for the 1970-71 academic year, the district submitted a court order to comply with Title VI of the Civil Rights Act and that court order was approved by HEW (its "assurance code" is equal to 3). This information was collected by OCR simultaneously with the computer-coded microdata on enrollment by race in each of a district's schools in fall 1970, used to construct the 1970 dissimilarity index.

6. White Private School Enrollment Rate (district): The 1970 white private school enrollment rate was constructed using district-level tabulations of the total population and the black population in the 1970 Census, reported in the 1970 Fourth-Count (Population) School District Data Tapes (U.S. Department of Education, 1970). The numerator is the sum of counts of (non-black) district residents (ages 3 to 34) enrolled in private school (kindergarten, elementary, or secondary). The denominator is the sum of (non-black) district residents in various age groups spanning 5 to 19. The Fourth Count school district data covers all districts with at least 300 students as of the 1969-70 school year. We lose very few districts due to this restriction given the typically large enrollments of Southern districts.

7. Pre-VRA Black Voter Registration Rate (county): Available data on black voter registration rates in the early 1960s for all states represented in our sample except Virginia were generously provided by James Alt (Alt, 1995). Pre-VRA voter registration rates in Virginia were hand-entered from Table 12 in U.S. Commission on Civil Rights (1968).

\footnotetext{
${ }^{6}$ Most of these districts are smaller districts in Tennessee. The survey included all districts "eliminating racially dual school systems under terms of voluntary plan agreements with [HEW] or under Federal court order regardless of school district enrollment size" (with the exception of such districts in Tennessee and Texas). It also included all districts with at least 3000 enrollment and smaller districts with the following probabilities: $75 \%$ for districts with 1200 to 2999 students, 50\% for districts with 600 to 1199 students, 25\% for districts with 300-599 students, and 0\% for districts with less than 300 students.
} 
8. Outlays on Federal Programs (county): Changes (1962 to 1969) in per-capita federal outlays to counties for public assistance (less food stamps), Medicare, Medicaid, and retirement and disability programs were constructed using data from the Regional Economic Information system, generously provided to us by Douglas Almond, Hilary Hoynes, and Diane Schanzenbach (Almond, Hoynes, and Schanzenbach, 2011). Federal outlays to counties for Head Start in 1972 were drawn from National Archives data and generously provided to us by Jens Ludwig and Douglas Miller (Ludwig and Miller, 2007).

\section{Estimation Sample}

School districts both consolidate and, less commonly, split apart during our sample period. We use the state school finance data referenced above to establish a history of these reorganizations and limit our working sample to districts that do not experience reorganization between 1961 and 1969 (1032 districts across nine Southern states). Our estimation sample includes all districts in this sample with data available the fiscal outcomes and the controls in the main specification the 1960 child poverty rate, 1960 black enrollment share, 1960 enrollment, 1948 Thurmond vote share, and whether the district was in one of the 300 poorest counties in 1960 (985 districts). We also trim districts from the sample for which changes in any of the four key outcomes over 1961 to 1964 or 1964 to 1969 lies more than 3.5 standard deviations away from the state-specific mean. Our final sample includes 922 districts.

\section{References}

Alabama Department of Education.Various Years. “Annual Report for the Scholastic Year Ending June 30, 1966 and for the Fiscal Year Ending September 30, 1966: Statistical and Financial Data.” Montgomery, AL.

Clubb, Jerome M., William H. Flanigan, and Nancy H. Zingale, Electoral Data for Counties in the United States: Presidential and Congressional Races, 1984-1972 [Computer file], Compiled by Jerome M. Clubb, William H. Flanigan, and Nancy H. Zingale, ICPSR08611-v1, (Ann Arbor, MI: Inter-university Consortium for Political and Social Research, 2006-11-13).

Denckla, Ben and Sarah Reber. 2006. “Documentation for Decoded OCR Files.” Unpublished.

Florida State Superintendent of Public Instruction. Various years. "Ranking of the Counties." Research Report, Division of Research. Tallahassee, FL.

Georgia State Department of Education. Various years. "Annual Reports of the Department of Education to the General Assembly of the State of Georgia.” Atlanta, GA.

Minnesota Population Center. 2004. “National Historical Geographic Information System: Prerelease Version 0.1.” Minneapolis, MN: University of Minnesota. http://www.nhgis.org. 
Mississippi State Department of Education. Various years. "Biennial report and recommendations of the State Superintendent of Public Education to the legislature for the scholastic year.” Jackson, MS: State Superintendent of Public Education.

North Carolina Education Association. Various years. "Per Pupil Expenditures for Current Expense: Information Provided by Division of Statistical Services State Department of Public Instruction.” Raleigh, NC.

South Carolina State Department of Education. Various years. "Annual Report of the State Superintendent of Education of the State of South Carolina.” Columbia, SC.

Southern Education Reporting Service. 1964. "A Statistical Summary, State By State, of School Segregation-Desegregation in the Southern and Border Area from 1954 to the Present.” Fourteenth revision. Nashville, TN: Southern Education Reporting Service.

Southern Education Reporting Service. 1967. “A Statistical Summary, State By State, of School Segregation-Desegregation in the Southern and Border Area from 1954 to the Present." Sixteenth revision. Nashville, TN: Southern Education Reporting Service.

State Department of Education of Louisiana. Various years. "Financial and Statistical Report." Baton Rouge, LA.

Tennessee Department of Education. Various years. “Annual Statistical Report of the Department of Education.” Nashville, TN.

U.S. Commission on Civil Rights. 1968. "Political Participation: A Study of the Participation of Negroes in the Electoral and Political Processes in 10 Southern States Since Passage of the Voting Rights Act of 1965.” Washington, D.C.: U.S. Government Printing Office.

U.S. Department of Commerce, Bureau of the Census. 1963. “Census of Population: 1960. Volume I: Characteristics of the Population. Washington, D.C.: U.S. Government Printing Office.

U.S. Department of Health, Education, and Welfare, Office of Education. 1967. "Statistics of State School Systems 1963-64.” Washington, DC: U.S. Government Printing Office.

U.S. Dept. of Education, National Center for Education Statistics. 1970. "User's Manual for 1970 Census Fourth Count (Population): School District Data Tape”. ICPSR version.

Washington, DC: U.S. Dept. of Education, National Center for Education Statistics. Ann Arbor, MI: Inter-university Consortium for Political and Social Research, 2004.

doi:10.3886/ICPSR03525

U.S. Department of Education, National Center for Education Statistics. 1970. “1970 Census Fourth Count (Population) School District Data Tapes.” Washington, DC. 
U.S. Senate. Committee on Labor and Public Welfare. Subcommittee on Education. 1965. "Maximum Basic Grants-Elementary and Secondary Education Act of 1965 (Public Law 81874, Title II, and Public Law 89-10, Title I).” Washington, DC: U.S. Government Printing Office.

U.S. Senate. Committee on Labor and Public Welfare. Subcommittee on Education. 1967. "Notes and Working Papers Concerning the Administration of Programs Authorized Under Title I of Public Law 89-10, The Elementary and Secondary Education Act of 1965 As Amended by Public Law 89-750.” Washington, DC: U.S. Government Printing Office.

United States Senate. Committee on Labor and Public Welfare. 1967. Subcommittee on Education. "County Allotments Under Title I, Elementary and Secondary Education Act, for Fiscal Year 1968 Based Upon \$1.2 Billion Appropriation Distributed Under Family Income Factors of \$2,000 and \$3,000 With County Savings Clause Added.” Washington, DC: U.S. Government Printing Office.

United States Senate. Committee on Labor and Public Welfare. Subcommittee on Education. 1970. "Allocation of Funds Under Title I of the Elementary and Secondary Education Act of 1965, As Amended, Fiscal Year 1970.” Washington, DC: U.S. Government Printing Office.

Virginia State Board of Education. Various years. "Annual Report of the Superintendent of Public Instruction of the Commonwealth of Virginia.” Richmond, VA. 


\section{Appendix B: Supplementary Analyses}

\section{Cost benefit analysis}

This section describes how we approximate the labor market returns to the additional educational attainment induced by Title I spending. We view this calculation as providing a rough approximation of the lower bound of potential benefits, as it ignores likely additional unmeasured private and social returns to this schooling - for example, improvements in health, reductions in criminal behavior, and increased civic participation.

Because we do not find a significant impact on educational attainment for blacks, the benefits in this calculation come solely from whites; the costs include all expenditures including those nominally allocated to black students. We estimate the benefits by applying the rate of return to additional schooling to annual wage income over one's career, and multiplying this present discounted value by our estimated change in probability that one graduates from high school. We assume a ten percent rate of return to an additional year of schooling, in the middle of the range of estimates in the relevant literature, and a five percent discount rate. We calculate the mean annual wage income from the 1970 Census, using white men and women ages 20-50 in our sampled states who finished tenth grade but did not graduate from high school. This mean (\$33,132 in 2009 dollars - all figures going forward are in 2009 dollars as well) is estimated unconditional on labor market participation; the mean conditional on positive earnings is $\$ 38,033$. Our preferred specification for outcomes results (see Table VI, Column 3) estimates that \$100 in Title I-induced spending per pupil yields a 3.1 percentage point increase in the likelihood of graduating from high school. For one year's wages, the estimated expected additional return from $\$ 100$ of Title I revenue is $\$ 81$ of annual wage income per person.

We estimate the costs of the program based on two different definitions of cost: (1) federal dollars spent on intergovernmental grants to school districts (this includes transfers to local consumption whose benefits we disregard but is what the federal government would use in calculating returns on its grants); and (2) current educational spending by school districts (relevant for the more general question of how money matters in educational production). The estimates in Table VI, Column 3 correspond to the latter concept.

From the district (current expenditure) perspective:

In our sample, the typical white student lived in a district with 75 percent white enrollment. Assuming that funds were distributed equally across students regardless of race, it would cost approximately $\$ 132$ per pupil to spend $\$ 100$ per white pupil. We estimate this using data for 1969, so the cohort generating this result on average received Title I funding (low variance across years) for five years to produce this attainment gain. We therefore compare our estimated benefits (associated labor market return expected from additional \$100 Title I revenue per pupil per year) with a cost of $\$ 132 * 5=\$ 660$. After 12 years of work, the expected benefit ( $\$ 692$ ) exceeds this amount; after 39 years of work, the expected benefit is double the cost.

From the federal (Title I revenue including crowded out funds) perspective:

We find that one dollar of Title I revenue per pupil increases current expenditure per pupil by $\$ 0.46$ (Table III, Column 2). \$132 of spending per pupil (the cost of spending \$100 per white 
pupil) therefore costs $\$ 287$ per pupil in federal revenue (287=132/.46) per year or $\$ 1435$ over five years. Considering these higher costs, the five-year intervention would be cost-effective only after 52 years of labor market returns to the additional education; again, this disregards all other benefits of the increased education spending and increased consumption due to crowd out.

\section{Income elasticity calculation}

We find that one dollar of Title I revenue per pupil increases current expenditure per pupil by \$0.46 (Table III, Column 2). We want to know how much spending would have been expected to increase in response to Title I based on the income elasticity of demand for education spending.

The increase in spending on education due to the grant is

\section{AddlSpending $=$ CounterfactualSpending $\times \eta \times \% \Delta$ IncomeDuetoGrant}

where $\eta$ is the (assumed) income elasticity of demand for education spending.

To estimate CounterfactualSpending for 1969 (what education spending would have been without Title I), we assume that in the absence of Title I, spending per pupil would have increased in line with income growth: We apply the assumed income elasticity of demand and the observed growth in median family income in the county ${ }^{7}$ to pre-program (1964) per-pupil current expenditure:

CounterfactualSpendingPerPupil $_{69}=$ SpendingPerPupil $_{64} \times \eta \times \% \Delta$ MedianFamilyIncome $_{64-69}$

We then multiply by enrollment to get total counterfactual spending:

$$
\text { CounterfactualSpending }_{69}=\text { CounterfactualSpendingPerPupil }_{69} \times \text { Enrollment }_{69}
$$

To estimate \% IncomeDuetoGrant, we divide the Title I grant by the number of families (to get the additional income per family implied by the grant, as if the grant were distributed as cash) and then divide by median family income in 1969:

$$
\% \Delta \text { IncomeDuetoGrant }=\frac{\text { TotalTitleIGrant }_{69} / \text { NumberFamilies }_{69}}{\text { MedianFamilyIncome }_{69}}
$$

We can then calculate the additional spending the Title I grant would be expected to generate for each county. To compare that to our coefficients, which indicate how much additional spending was generated for each additional dollar of Title I revenue, we divide the implied additional spending by the total Title I grant. Using this method, we calculate the expected additional spending for a range of income elasticities reported in the literature, 0.40 to 0.65 (Fisher and

\footnotetext{
${ }^{7}$ We assume that half the change in median family income at the county level (obtained from the County and City Data Book) from 1960 to 1970 occurred from 1964 to 1969.
} 
Papke, 2001). These estimates are consistent with spending increases of $\$ 0.12$ to $\$ 0.19$ per dollar of Title I revenue. 